\title{
Mixing Characteristics under Tide, Meteorological and Oceanographic Conditions in the Euboean Gulf Greece
}

\author{
Evangelos Tsirogiannis, Panagiotis Angelidis, Nikolaos Kotsovinos \\ Division of Hydraulics, Department of Civil Engineering, Democritus University of Thrace, Kimmeria Campus, Xanthi, Greece \\ Email: pangelid@civil.duth.gr
}

How to cite this paper: Tsirogiannis, E., Angelidis, P. and Kotsovinos, N. (2019) Mixing Characteristics under Tide, Meteorological and Oceanographic Conditions in the Euboean Gulf Greece. Computational Water, Energy, and Environmental Engineering, 8, 99-123.

https://doi.org/10.4236/cweee.2019.84007

Received: September 27, 2019

Accepted: October 20, 2019

Published: October 23, 2019

Copyright $\odot 2019$ by author(s) and Scientific Research Publishing Inc. This work is licensed under the Creative Commons Attribution International License (CC BY 4.0).

http://creativecommons.org/licenses/by/4.0/

\section{(c) (i) Open Access}

\begin{abstract}
The mixing characteristics in the marine environment of the Euboean Gulf are studied. The Estuarine and Lake COmputer Model three-dimensional hydrodynamic model has been used, to simulate numerically the effects of the strong tide conditions, the atmospheric forcing, and the oceanographic conditions. Water age was calculated in all computational cells and its renewal was examined with the "pure" water of the open sea both on the surface layers, where the effect of tide and wind was pronounced, as well as on the deeper layers and bottom. It was investigated if in surface layers the tide and the wind restore the water of the study area, thus preventing its renewal. In the remote area, the mixing and dilution of the pollutants contained in the treated municipal waste of five installed diffusers in this complex hydrodynamic field, generated by the aforementioned loads, is simulated. It was found that even a slight stratification density has the effect of restricting the vertical mixing and entrapment of dirt in the deeper layers. The combined impact of municipal waste effluents on selected areas of high economic, tourist and environmental value in the Euboean Gulf was assessed. It was found out, that the Diffuser 2 has a great effect in all the five selected areas, because it has greater waste water discharge and because of the tide, who produce a velocity field and transfer the pollutants in longer distances. It was also investigated indicatively in an important area, whether the presence of tide contributes to better mixing and dispersing of pollutants and to better water quality or, on the contrary, as it restores remote pollutants that were released earlier.
\end{abstract}

\section{Keywords}

Sewage Mixing, Water Age, Tide, Gulf of Evoikos, Greece 


\section{Introduction}

The hydrodynamic circulation in coastal systems is often depending on various interacting processes such as tides, waves, and river inflows. Many researchers have spent their effort to model the effects of the tide [1]-[6]. Hydrodynamic processes significantly influence the mixing and transport of pollutants in coastal waters. Additionally, the tidal currents transport pollutants back and forth before sometime dispersing them into the sea [7].

In the Eastern Mediterranean the tidal currents are in general relatively weak and in most case have low speeds [8]. One of the earliest historically observed tidal phenomenon is in the Gulf of Evoikos (Greece). Eratosthenes, Pitheas, Posidonios [9], Stravon and Senekas [10] have studied this phenomenon in antiquity and other researchers from the early 20th century [9]-[14]. Although some research has been carried out in the wider area of southern Europe [15] [16] [17] [18] on sea level changes, but also within the Euboean Gulf [19] [20], there are still no systematic measurements and several available work today to describe and illustrate the various effects of tide on hydrodynamic circulation, as well as on diffusion and transport of pollutants [21].

The ELCOM (Estuarine and Lake COmputer Model) model, which was developed in the Center of Water Research in the Western Australia University, is a very good numerical model, for the hydrodynamic simulation of lakes, estuaries and enclosed seas. This model has been used very well in various relevant studies around the world, such as in the North Aegean Sea [22] [23], in the Adriatic Sea [24], and in the Persian Gulf [25], a study in which also included a simulation of the tide. The water circulation in the North and South Euboean Gulf has been simulated in a recent work of the authors' [21] with the use of the ELCOM model.

As a result of the above mentioned, there is a lack of knowledge in literature for the tidal dynamics taking effect on the interconnected system of the North and South Gulfs of Evoikos. There is a lack of information on the tidal hydraulics and the tidal exchange of the two Gulfs, which are connected through a narrow and shallow channel. Only in a previous work of the authors' [21] a computational simulation of the hydrodynamic circulation has been carried out in order to investigate the natural and hydrodynamic characteristics of this tidal flow, including, among others, the velocity field, the salinity, the water temperature, the density stratification, the water circulation, the flow rates, etc. But there is still a gap of knowledge for if and how these hydrodynamic characteristics influence the horizontal dispersion and the vertical mixing of the marine masses and, consequently, the mixing and dilution of various pollutants, as well as the water renewal in the Gulf of Evoikos. The present paper comes to fill this gap and give answers to these questions.

In the present work, the effects of the tide conditions, the atmospheric forcing, and the oceanographic conditions in mixing and transport of pollutants are computationally simulated. It was investigated the renewal of waters of Euboean 
Gulf with the "pure" water of the open sea by calculating the age of the water in all computational cells. The renewal has been tested both on the surface layers, where the effect of tide and wind is stronger, as well as on the deeper layers and also on the bottom. The mixing, transport, and dilution of pollutants in the distant region within the complex hydrodynamic field, generated by the aforementioned charges, were simulated. These pollutants are included in the treated municipal waste of five installed diffusers operating in the area. The effect of density stratification on limiting vertical mixing and entrapment of pollutants in the deeper layers was investigated. The combined impact of municipal waste effluents on selected areas of high economic, tourist and environmental value in the Euboean Gulf was assessed.

\section{Materials and Methods}

The study area (Figure 1) consists of the Northern Euboean Gulf with a total surface area of $1060 \mathrm{Km}^{2}$ and the Southern Euboean Gulf with an area of 900 $\mathrm{Km}^{2}$. Communication between these two atria is through Evripus Channel which substantially is a narrow and shallow $40 \mathrm{~m} \times 40 \mathrm{~m} \times 10 \mathrm{~m}$ canal, with the main characteristic of being strong tides [20]. It is typically reported that during the semi-period ( $\mathrm{T} / 2=6$ hours) the maximum flow velocity in the Strait of Euripus is about $2.5 \mathrm{~m} / \mathrm{s}$ [26] [27].

The water circulation and pollutant mixing and transport in the North and South Euboean Gulf have been simulated using the ELCOM three-dimensional, finite difference hydrodynamic model, which has been developed for the simulation of lakes and enclosed seas. The model solves the system of the unsteady Reynolds-averaged Navier-Stokes (RANS) equations for incompressible flow and the scalar transport equations. It uses the Boussinesq approximation omitting the non-hydrostatic pressure terms. The change of the level of the free water surface is estimated by integrating vertically the continuity equation applied to the Reynolds-averaged kinematic boundary condition [28] [29]. The RANS equations are solved and the closing of the turbulent flow equation system in the horizontal direction is achieved using a turbulent viscosity coefficient, while, for the vertical direction, it is usinga vertical energy layer mixing model. The ELCOM model takes into account the meteorological load, such as the effect that the solar radiation, the wind, the rainfall, and other meteorological parameters have on the surface layer of the water. The model also can simulate the influence of the tide.

The South Euboean Gulf and a part of the North Euboean Gulf chosen for the numerical simulation of the hydrodynamic circulation. A rectangular computational grid constructed with cells of variable dimensions, ranging between $40 \mathrm{~m}$ $\times 100 \mathrm{~m}$ and $400 \mathrm{~m} \times 400 \mathrm{~m}$. The width of the $40 \mathrm{~m}$ of the Evripus straits imposed the lower limit of the cells' dimensions. The gradual change of the computational cell dimensionsup to $400 \mathrm{~m}$ was necessary in order to avoid creating an excessive number of cells, which would have made the computational code impossible to execute. Because of these restrictions, the numerical simulation 


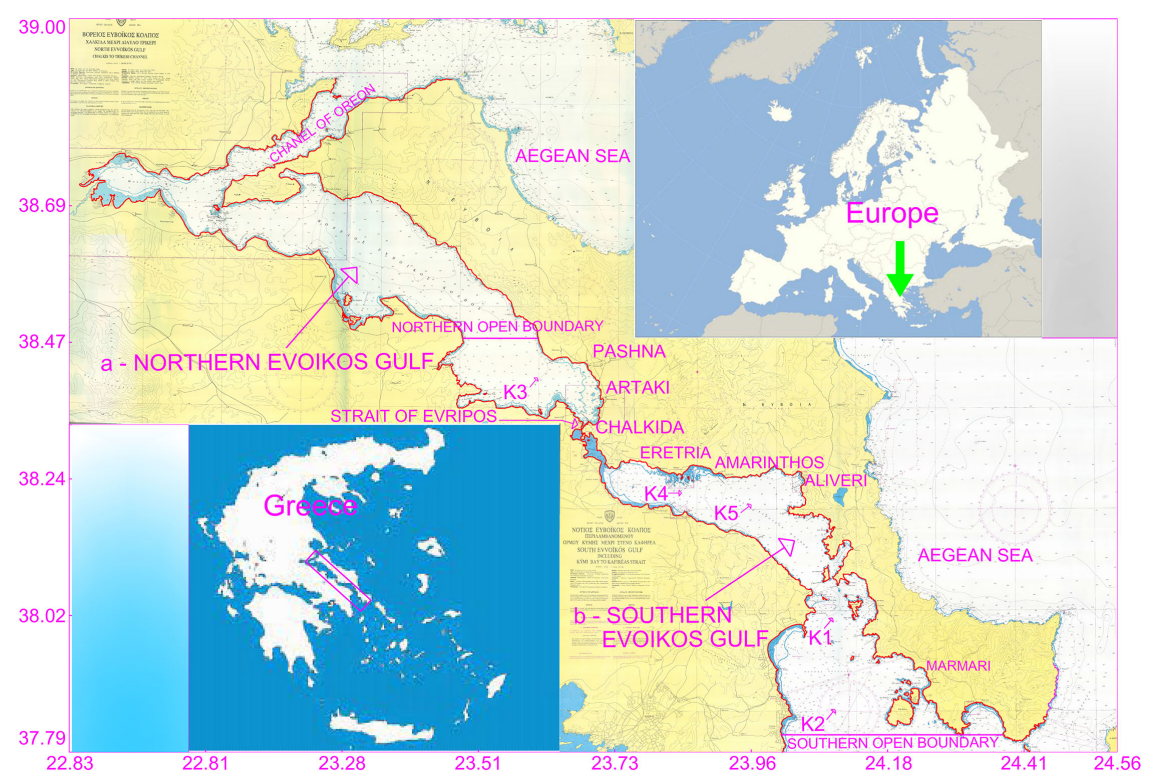

Figure 1. Map of the northern and the southern Gulf of Evoikos.

included the entire southern Euboean Gulf and (1/3) of the northern Euboean Gulf. Otherwise, if the computational domain extended to include the whole of the northern Euboean Gulf, the number of computational cells increased dramatically and the computational code was not possible to execute. The southern Euboean Gulf is of higher economic, tourist and environmental value compared to the northern Euboean Gulf. This is the reason for its complete inclusion in the numerical simulation. Moreover, four of the total five waste water diffusers have been installed in the southern Euboean Gulf, and the fifth one is located near the interconnection of the two Gulfs. In Figure 1, the northern and southern boundaries of the computational domain are illustrated.

In the vertical direction a total of 20 layers were set with variable thickness ranging from $2.5 \mathrm{~m}$ to $5.0 \mathrm{~m}$ [21]. The progressive increase in thickness chosen in order to: 1) simulate as precisely as possible the hydrodynamic circulation of the Euripus Strait, which has a depth of only $10 \mathrm{~m}$, and which is very important for the water exchange between the northern and southern Euboean Gulf, 2) describe better the results at the shallow coastal areas of special interest, and 3) accomplish the best accuracy regarding the vertical distribution of the density stratification, the tracers' concentrations, the velocity field, and other characteristics. The computational domain consisted of 225,351 active water cells, and the maximum simulation depth extended up to $-86.0 \mathrm{~m}$.

"Open" boundary conditions implemented in the northern and southern boundaries of the simulation area, which passively let the water inflow to, or outflow from each boundary cell, according to the needs of the flow. Based on literature measurements [10] [19], boundary conditions of the sea level variance were forced on the northern and southern domain boundaries in order to simulate the tide, according to Figure 2.

Meteorological data were imported every 10 minutes, such as the wind speed 
and direction, the air temperature, the solar radiation, the rainfall, the atmospheric pressure, and the relative humidity (Figure 3). The simulation time period was one year (2016), which was considered as a representative typical year. More details about initial and boundary conditions as well as the validation of the simulation are presented in [21], in which a hydrodynamic circulation has been carried, and which was the basis for the present work, where the mixing and dilution of various pollutants are examined as well as the water renewal in the Gulf of Evoikos. Analogous validations for similar simulation techniques were made by [22] [23] in comparable problems.

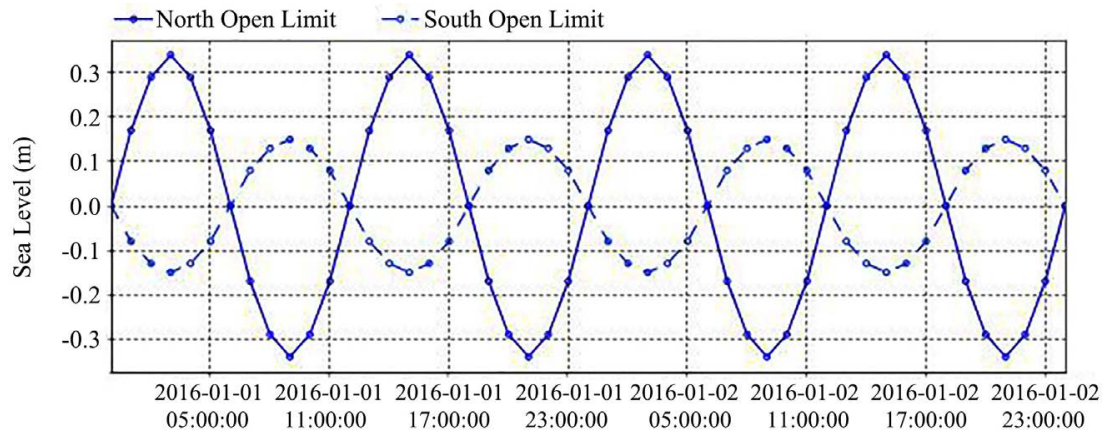

Figure 2. Tidal sea level variations at the northern and southern boundaries of the computational domain for 48 hours.
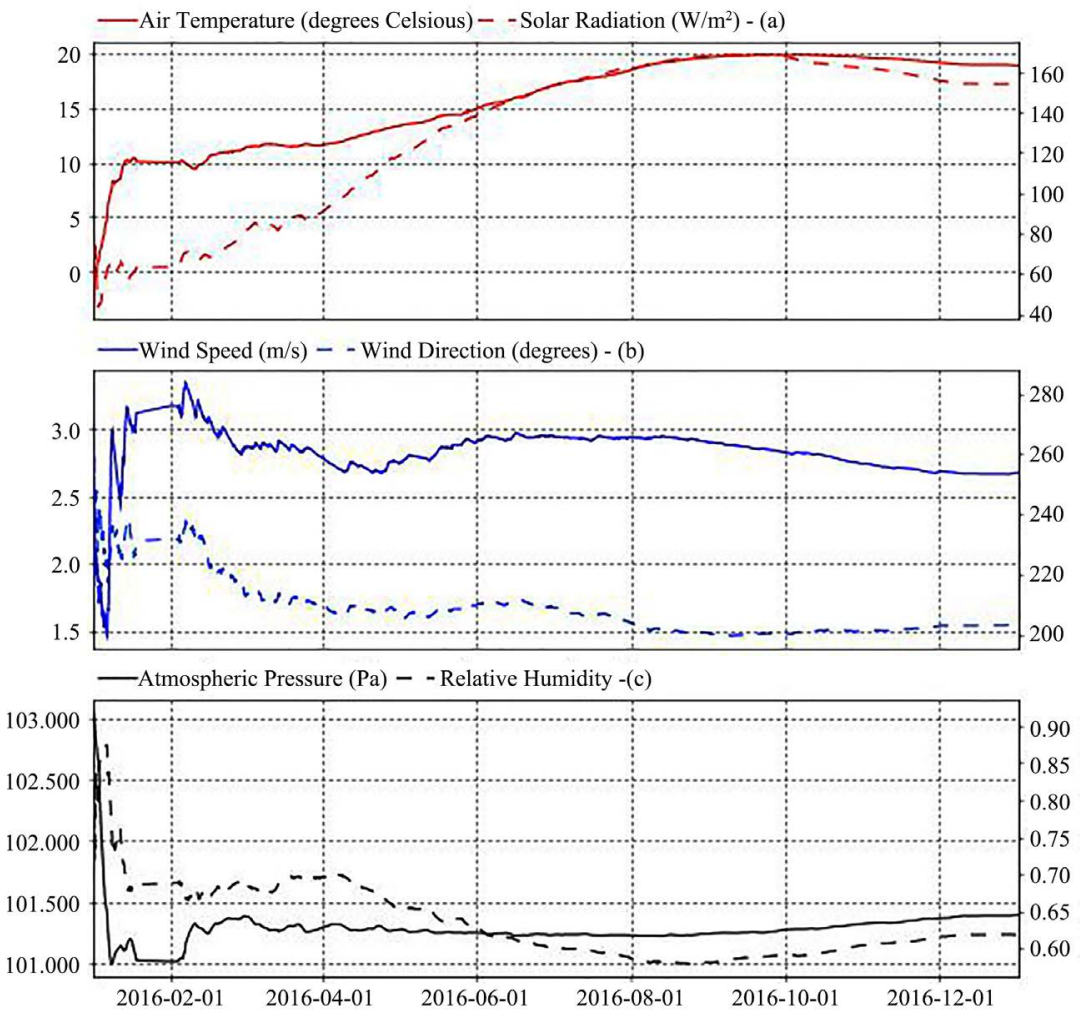

Figure 3. (a) Air temperature and solar radiation, (b) Wind speed and direction, (c) Atmospheric pressure and relative humidity, per 10 minutes for the year 2016 in the study area. 
The water entering into the computational space, from the two open boundary conditions, coming from the North and South Aegean seas is simulated using two conservative tracers (tracer-north, tracer-south). These two indicators having dimensionless concentration between 0 to 1 , aimed at monitoring the source of the waters in each cell of the computational domain and their mixing with the waters of Evoikos, during the progress of the simulation.

\section{Results}

\subsection{Water Age Modeling}

ELCOM has the ability to calculate the age of the water in each cell. At the start of the simulation, the age of each cell in the computing space is set to zero and then increased each time by the computational time step. Water, which enters the open boundary conditions, is of zero age. So if, for example, on the 200th day of the simulation, a cell consists of $60 \%$ of the water coming from the computing space and $40 \%$ of the water entering the computing field 80 days before, then the average retention time or the average age of the water in this cell is: $60 \% \times 200+$ $40 \% \times 80=152$ days and is always shorter than the time of simulation until this time $(152<200)$.

The average residence time (age) of water in the surface computational cells of the simulated Euboean Bay region in the middle of March, June, September and November of the typical year (2016) is shown in Figure 4. As it is shown in Figure 4, the water age at the surface is significantly reduced in the southern part of the southern Euboean Gulf due to the inflow from the southern boundary condition. In the northern part of the Southern Euboean it is observed that at the 75th day of simulation (mid-March) the mean age of surface water is around 60 days. Accordingly, in mid-June, i.e. the 165th day of simulation the average age in the same area is 80 days, i.e. decreased age of water at $80 / 165=48 \%$. Also, in mid-September the age of surface water was correspondingly reduced to 100/255 = $39 \%$, while in mid-November to $110 / 315=35 \%$ of real age. Consequently, both tide and meteorological charge, as well as oceanographic conditions, contribute significantly to the reduction of surface water age in the southern part of the southern Euboean gulf but also considerably in the northern part of the same gulf.

Figure 5 again shows the average water retention time, but in the bottom computational cells, at the same times. In the northern part of southern Euboea it is observed that in mid-March the mean age of the bottom water is around 70 days, which is slightly higher than the surface water. In mid-June, the mean age in the same region varies in the bottom cells from about 80 to 140 days, and is therefore longer than the surface water age. Also, in mid-September appears again in the bottom water age of $100-180$ days, that is greater than the surface. But in mid-November the situation is reversing. Almost the entire South Euboean Gulf is occupied at the bottom by water coming from the southern open boundary condition, and therefore represents a water age of only 20 days, as opposed to the surface water age of 100 days. In addition, to this important con- 
clusion, it should be added that the color gradation of Figure 4 and Figure 5 indicates that some regions in the northern part of southern Euboean Gulf have longer residence times compared to balances of the computational domain.

For the better investigation of the above phenomenon, Figure 6 depicts the change in depth of water retention time at various time points at three selected points K4, K5 and K1 (Figure 1) of the South Euboean Gulf. As it is clear to

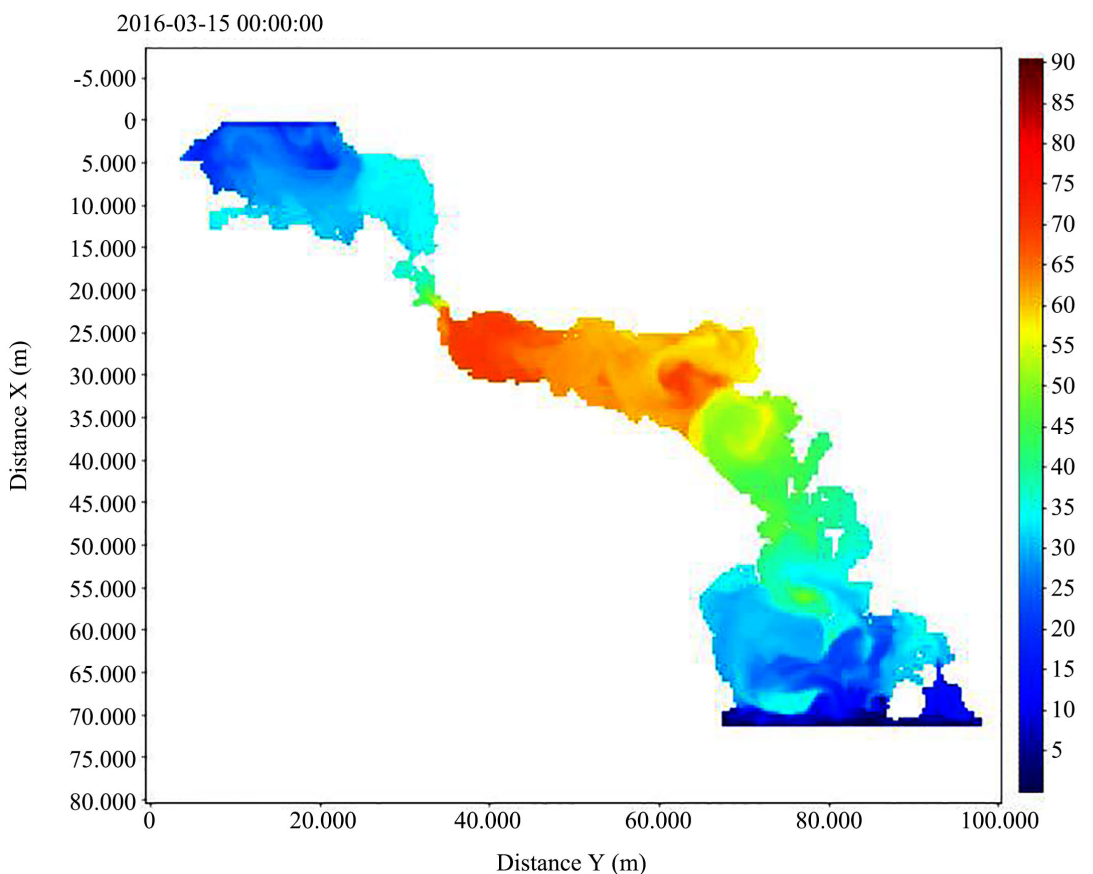

(a)

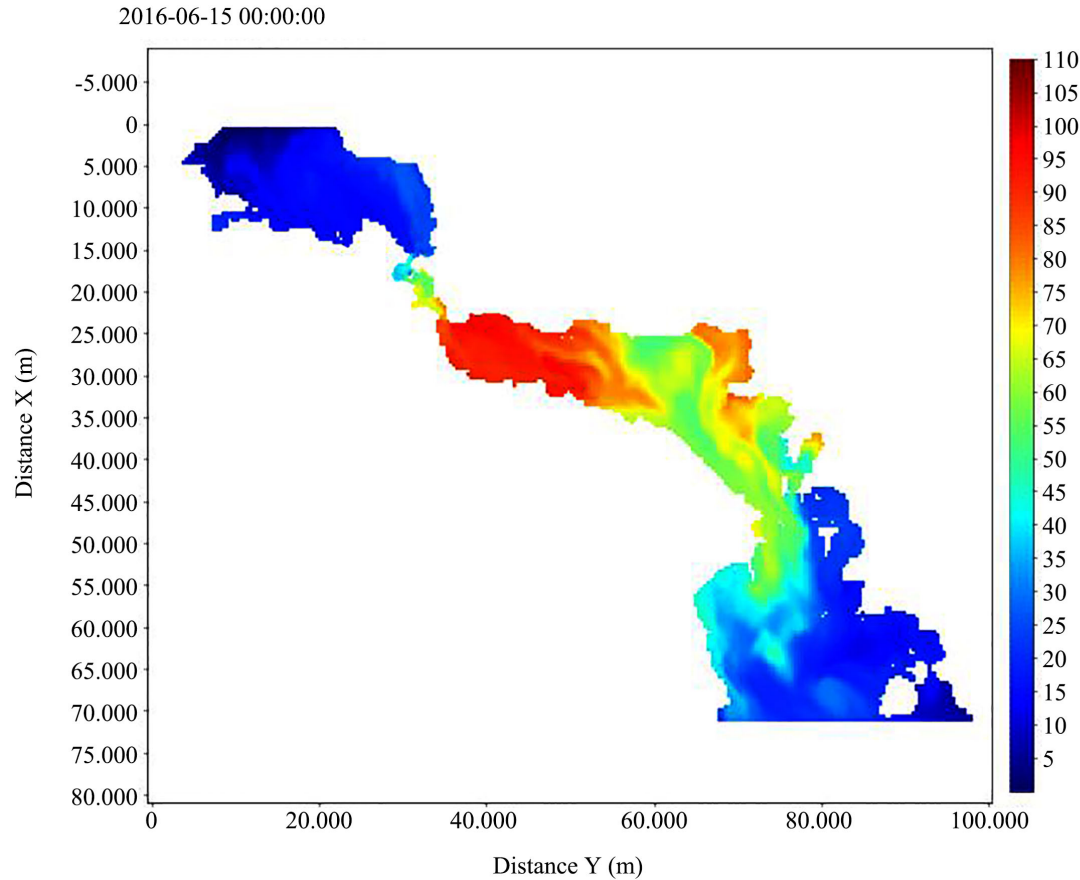




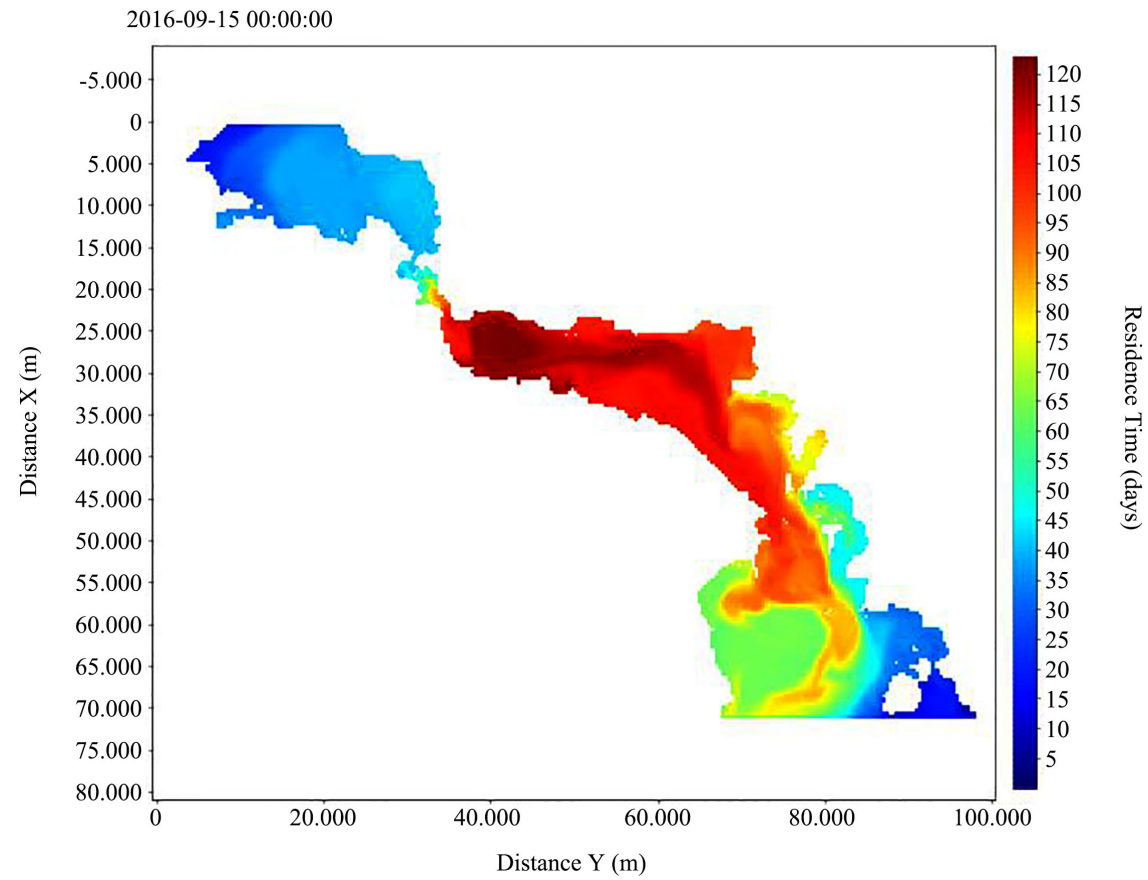

(c)

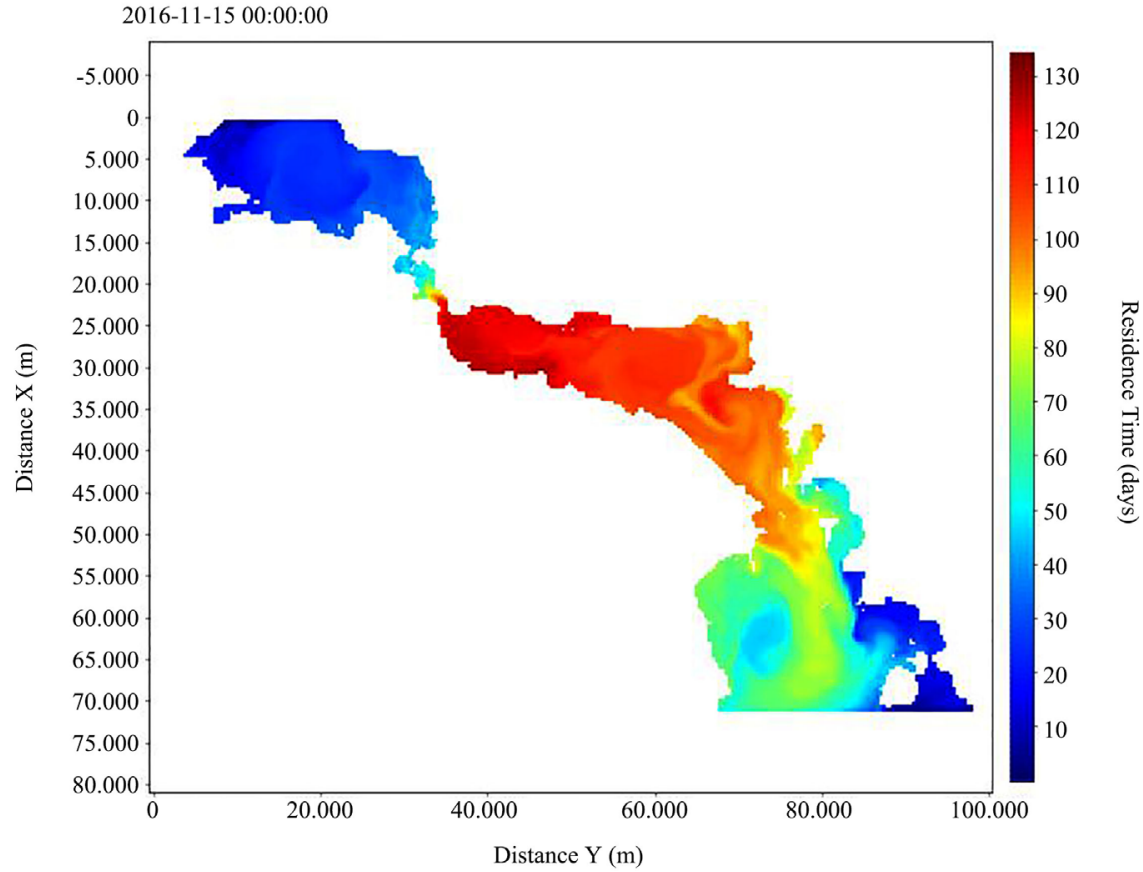

(d)

Figure 4. Average residence time of water in the surface cells of the Euboean Gulf in the middle of the month: (a) March, (b) June, (c) September and (d) November.

point K4 (Figure 6(a)), the first month of March, the water residence time remains nearly uniform throughout the depth, while in June increased. In September, K4 shows a longer age of water near the free surface to about $10 \mathrm{~m}$ depth and a lower age of water in the deeper layers to the bottom. In November, K4 
shows the highest water age at almost all depths of the water column, with the exception of near the bottom at depths greater than $30 \mathrm{~m}$. Similar behavior of water age occurs both at point K5 (Figure 6(b)) and at point K1 (Figure 6(c)) for the upper layer of about $30-35 \mathrm{~m}$ depth. It is worth noting that both at point $\mathrm{K} 5$ and at point $\mathrm{K} 1$, which have greater depths $(67 \mathrm{~m}$ and $57 \mathrm{~m}$ respectively) than point $\mathrm{K} 4(37 \mathrm{~m})$, the residence time of water for depths greater than $35 \mathrm{~m}$ is

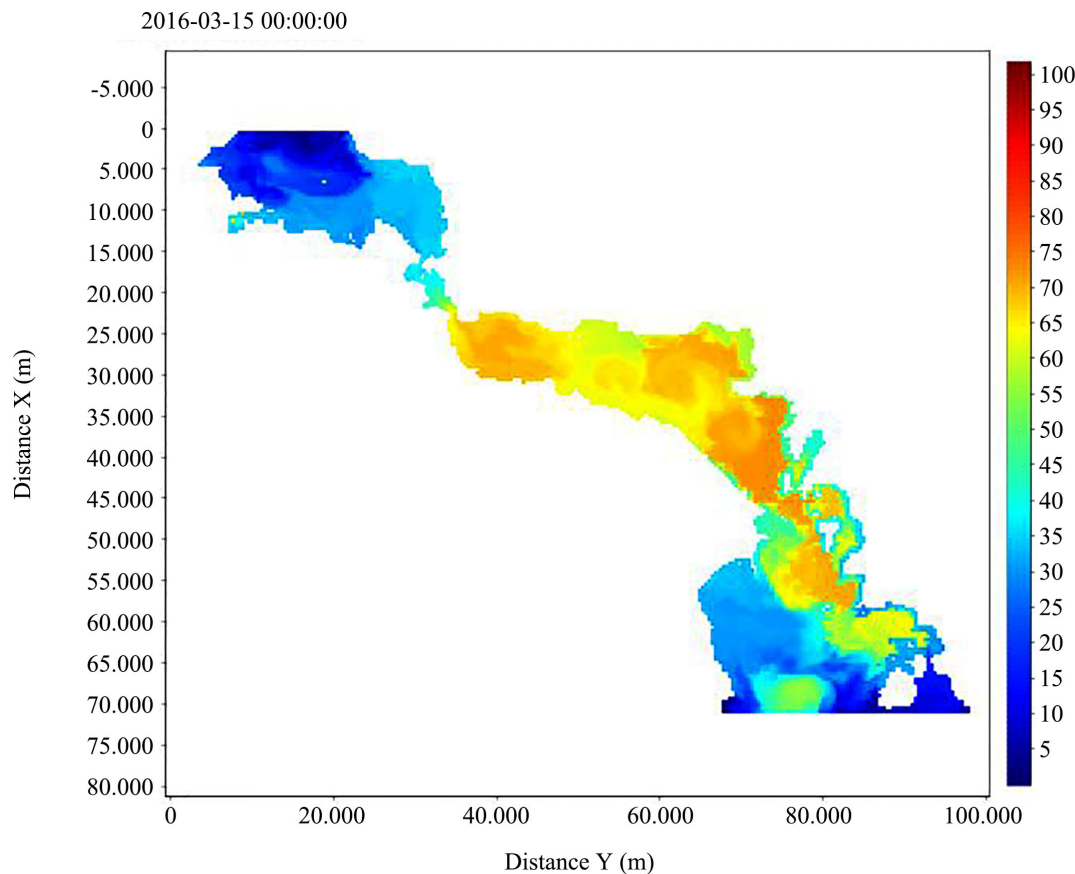

(a)

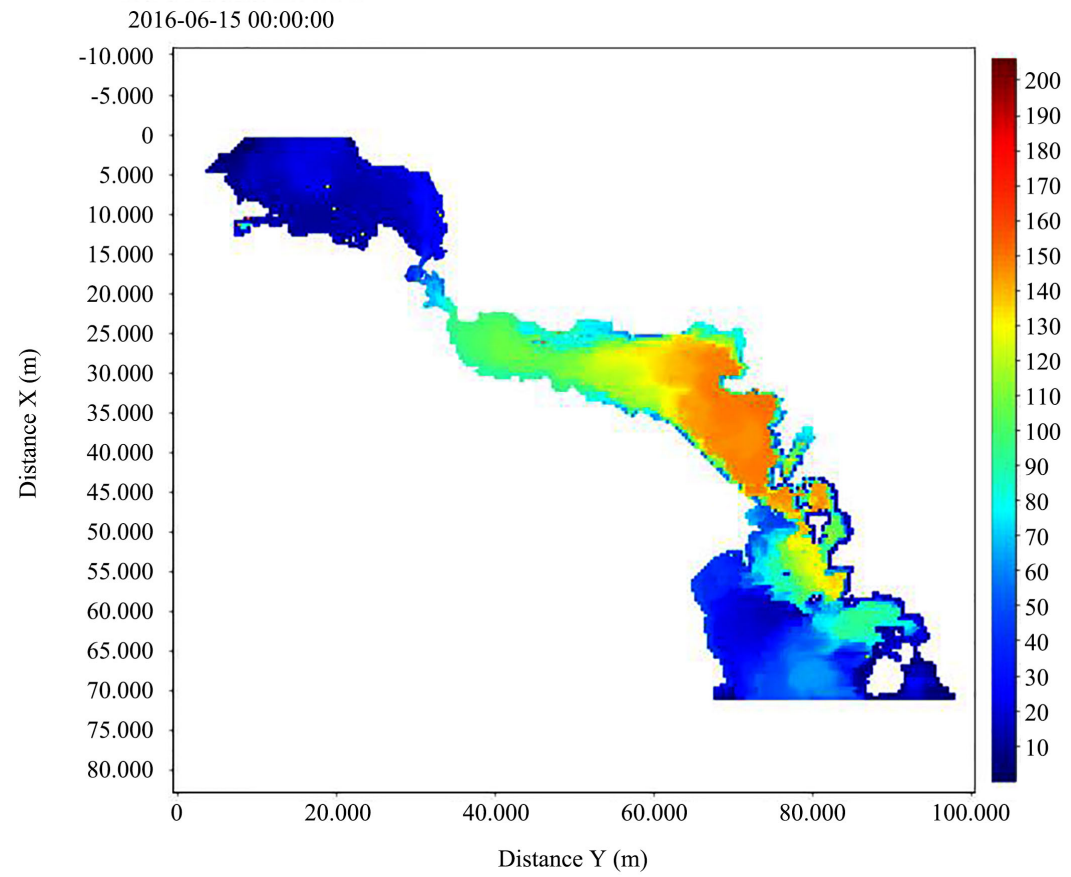




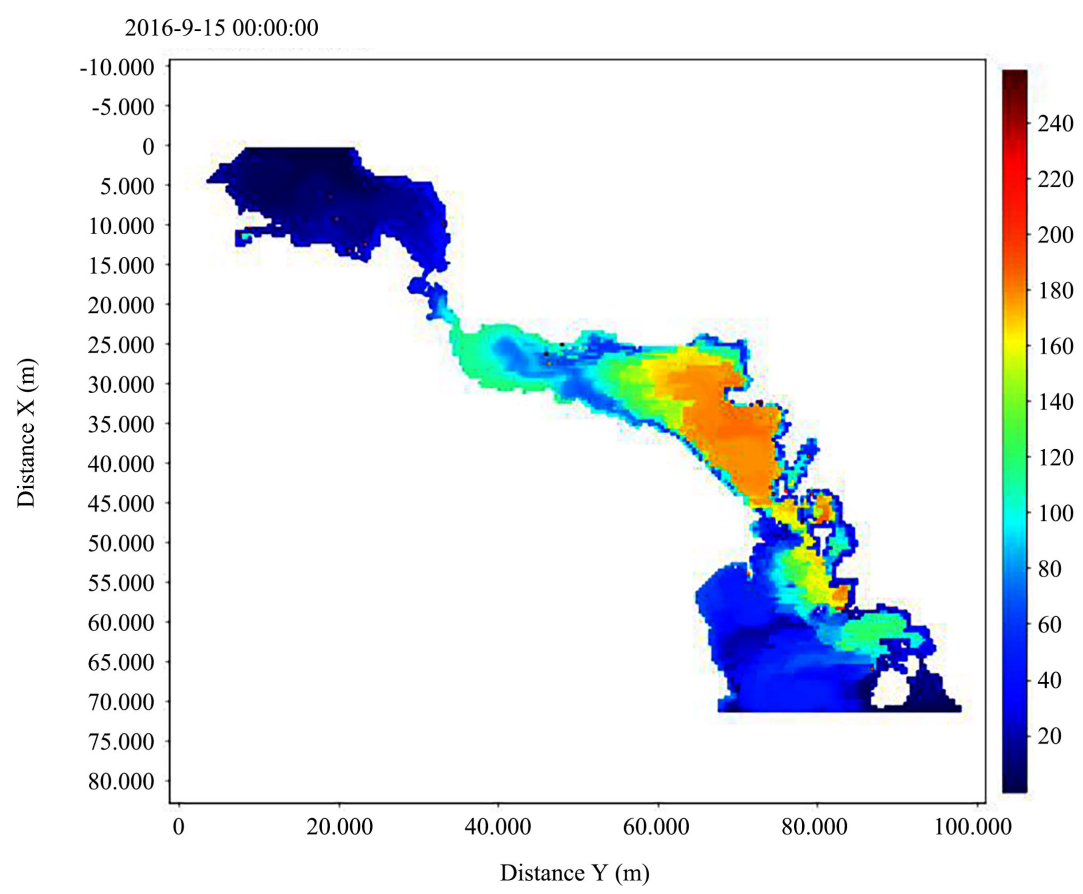

(c)

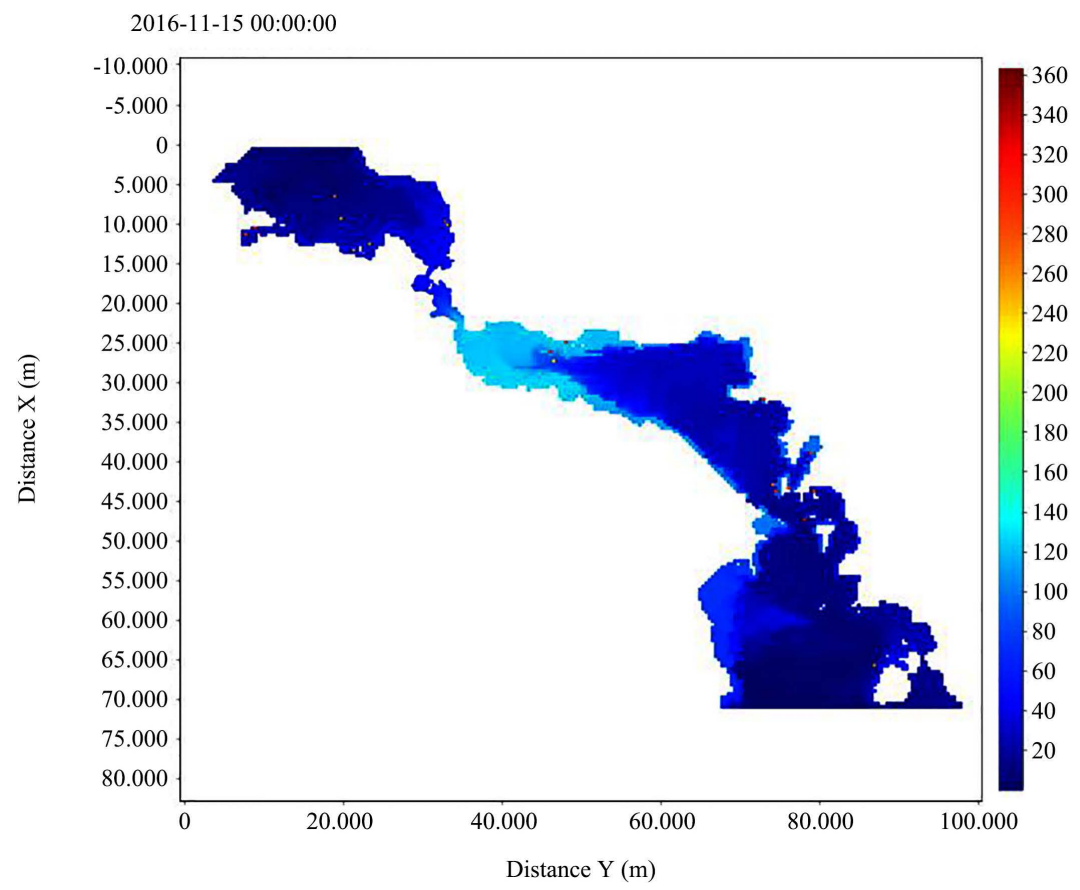

(d)

Figure 5. Average residence time of water in the bottom cells of the Evian Gulf in the middle of the month: (a) March, (b) June, (c) September and (d) November.

reduced dramatically during the month of November in about 20 days. That is to say, in the deeper layers, there is almost complete water replenishment derived from open boundary conditions, while in the upper layers, where the impact of both tide and wind is more pronounced, the age of the water remains significantly older. 


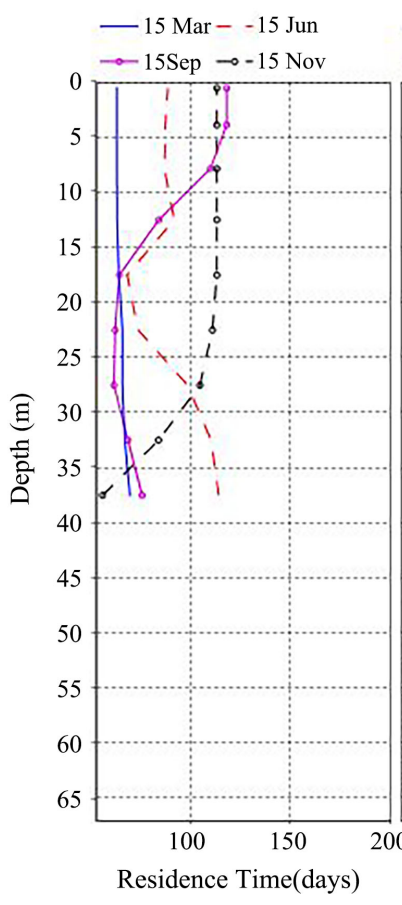

(a)

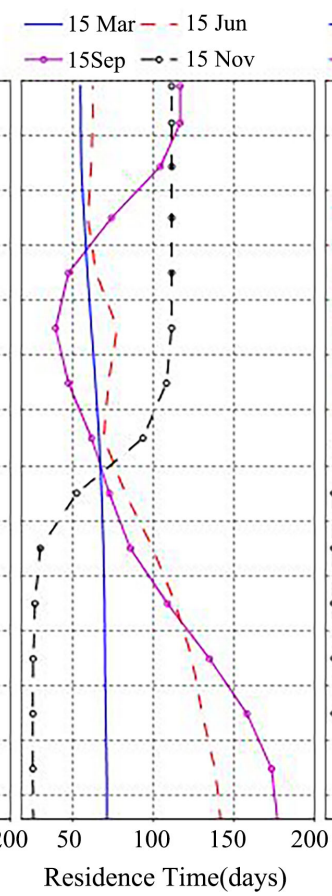

(b)

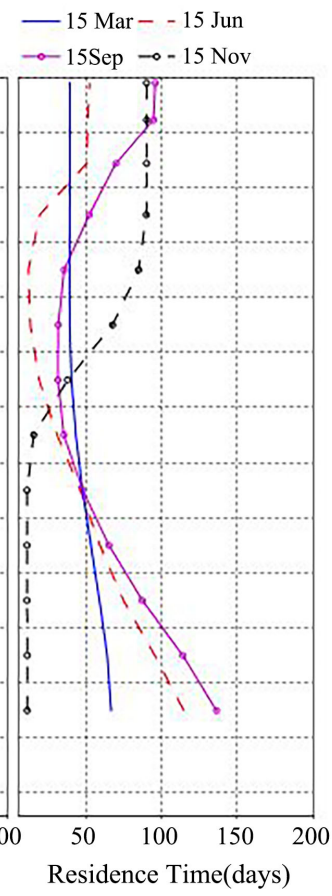

(c)

Figure 6. Depth change of the mean water residence time at the locations: (a) K4, (b) K5 and (c) K1 of the Southern Euboean Gulf, in mid-March, June, September and November.

These results are illustrated by Figure 7, where the same points K4, K5 and K1 and for the same time points show the concentration of the tracer-south, which expresses, in each cell of the computational space of the Evoikos Gulf, the water concentration which enters from the South Aegean Sea through the open southern marginal condition. As can be seen, the concentrations of tracer-south (Figure 7) vary in depth inversely with the water residence times (Figure 6) at the same time points. Also, at depths greater than $30-35 \mathrm{~m}$ (Figure 7(b) and Figure $7(\mathrm{c})$ ), the concentration of tracer-south in November tends to 1.0, which means complete renewal of water in these cells, which occurred about 20 days ago, provided that such is the residence time (Figure 6(b), Figure 6(c)).

It can be concluded from the above that tide and wind mainly have an effect on the surface layers and less on the deeper ones. Also on the surface layers, the tide and the wind restore the water of the computing space, thus preventing its renewal with the "pure" water of the open sea, which enters the southern boundary condition. On the contrary, the renewal of water is almost complete in the deeper layers of the Southern Euboean Gulf, after about 11 months.

\subsection{Sewage Mixing}

Five (5) submarine pipelines-through diffusers-processed municipal wastewater are installed within the research area. Table 1 gives the names of the diffusers, the names of the areas where they are installed, the names of the corres- 
ponding tracers, the depth of disposal, the discharge of the liquid waste and the initial concentration of the suspended solids contained therein. Figure 8 shows the positions of the submarine pipelines as well as some of the control points designated in the present investigation (P1, P2, P3, P4, P5).

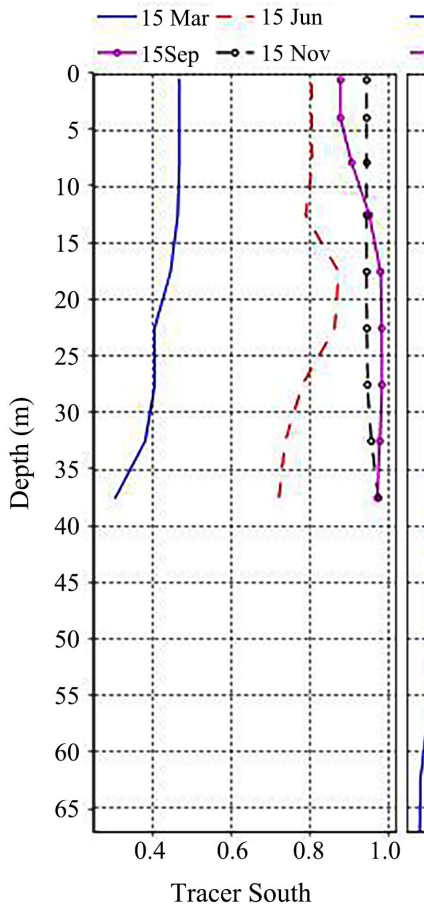

(a)

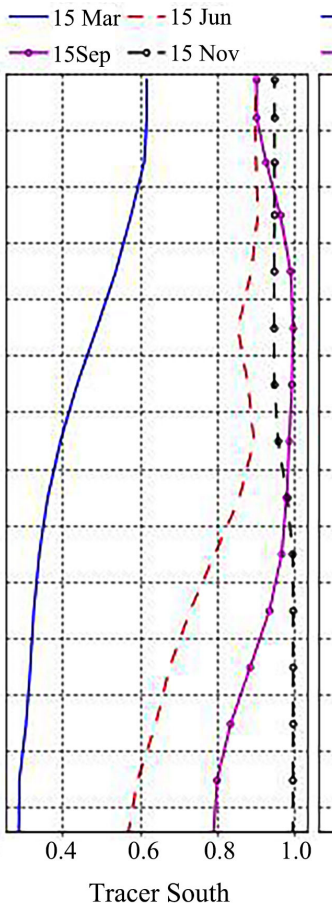

(b)

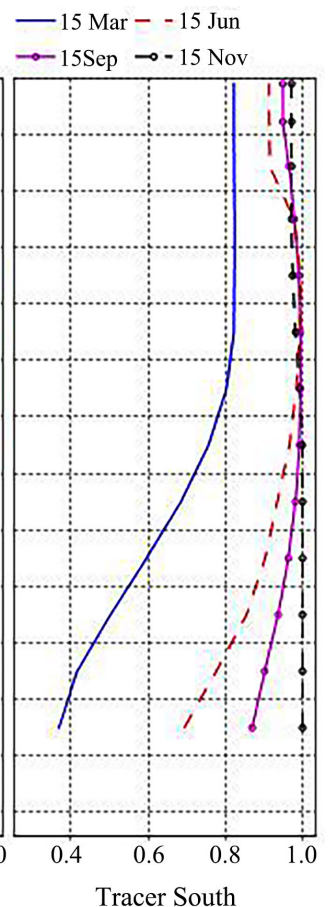

(c)

Figure 7. Depth change in tracer-south concentration at sites: (a) K4, (b) K5 and (c) K1 of the Southern Euboean Gulf, in mid-March, June, September and November.

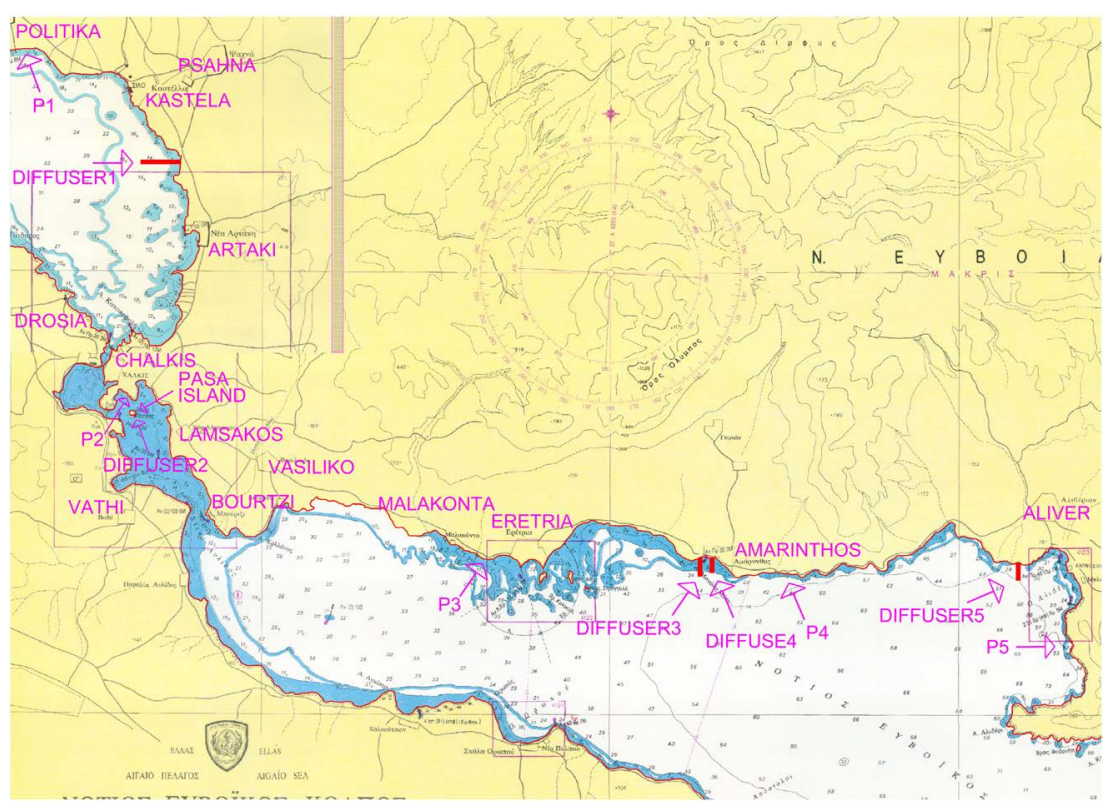

Figure 8. Locations of submarine pipelines for municipal waste water disposal in the Euboean Bay and designated control points in coastal areas. 
Table 1. Disposal characteristics of treated municipal waste through diffusers.

\begin{tabular}{ccccccc}
\hline No. Diffuser's name & $\begin{array}{c}\text { Name of } \\
\text { the area }\end{array}$ & $\begin{array}{c}\text { Tracer's } \\
\text { name }\end{array}$ & $\begin{array}{c}\text { Depth of } \\
\text { disposal }(\mathrm{m})\end{array}$ & $\begin{array}{c}\text { Discharge of } \\
\text { municipal waste } \\
\left(\mathrm{m}^{3} / \mathrm{s}\right)\end{array}$ & $\begin{array}{c}\text { Concentration } \\
\text { of suspended } \\
\text { solids }(\mathrm{mg} / \mathrm{l})\end{array}$ \\
\hline 1 & DIFFUSER 1 & KASTELA & Tracer 3 & 18 & 0.04 & 10 \\
2 & DIFFUSER 2 & CHALKIS & Tracer 4 & 10 & 0.24 & 35 \\
3 & DIFFUSER 3 & ERETRIA & Tracer 5 & 24 & 0.04 & 35 \\
4 & DIFFUSER 4 & AMARINTHOS & Tracer 6 & 19 & 0.03 & 30 \\
5 & DIFFUSER 5 & ALIVERI & Tracer 7 & 47 & 0.04 & 25 \\
\hline
\end{tabular}

An interesting question that arises is how tide, atmospheric charge and bathymetry influence the mixing and dilution of the pollutants contained in these treated municipal wastes. The mechanics of the discharge of these pollutants into the near filed through the two-dimensional buoyant jets are not examined, but the mixing in the far field in the complex hydrodynamic area created by the aforementioned loads is simulated with the ELCOM model. The description of conservative pollutants contained in urban waste water is provided in the form of conservative tracers. Thus, in each diffuser outlet, a conservative tracer (Table 1 ) is assigned a dimensional concentration value of 1 . The discharge of each diffuser and the concentration of each tracer are assumed to enter the computational cell located above the diffuser. Because the computational cell measuring $40 \mathrm{~m} \times 100 \mathrm{~m} \times 5 \mathrm{~m}$ or larger contains a significant volume of water, the incoming tracer concentration in this cell appears to be well below 1 , as the amount of pollutant contained in the effluent discharges with tracer concentration equal to 1 , enters a much larger volume of water.

From the annual simulation of a typical year, results from two time periods, one winter (6-3-2016) and one summer (14-7-2016), are selected and presented. The winter time was selected by the criterion of low temperature, but also its sufficient distance from the first day of simulation, so as to have a "warm up", the computational model and to restore the hydrodynamic field without affecting it from the initial conditions. Both winter and summer were selected as low wind days to better determine the effect of the tide. The mean daily air temperatures were $12.59^{\circ} \mathrm{C}$ and $27.85^{\circ} \mathrm{C}$ on these two dates and the mean daily wind speeds were $1.26 \mathrm{~m} / \mathrm{s}$ and $1.38 \mathrm{~m} / \mathrm{s}$, respectively.

Figure 9 is a chromatic representation of the dimensional concentration of tracer 7, which comes from the disposal of municipal waste water by Diffuser 5 in the Aliveri area, at the selected winter time (6-3-2016), both on the surface (Figure 9(a)) and on the bottom (Figure 9(b)). It is observed that on the surface the dispersion field is wider than the bottom one and that the surface concentrations are lower than the bottom, which is to be expected. In the same region, the corresponding results for tracer 7, but for summer time (14-7-2016), show much lower surface concentrations (Figure 10(a)) than the bottom (Figure 10(b)). In addition, smaller concentrations (Figure 10(a)) are observed on the surface 
during the summer time compared to the corresponding concentrations on the surface of the winter time (Figure 9(a)). This observation is an indication of density stratification, the existence of which may prevent vertical mixing during the hot season.

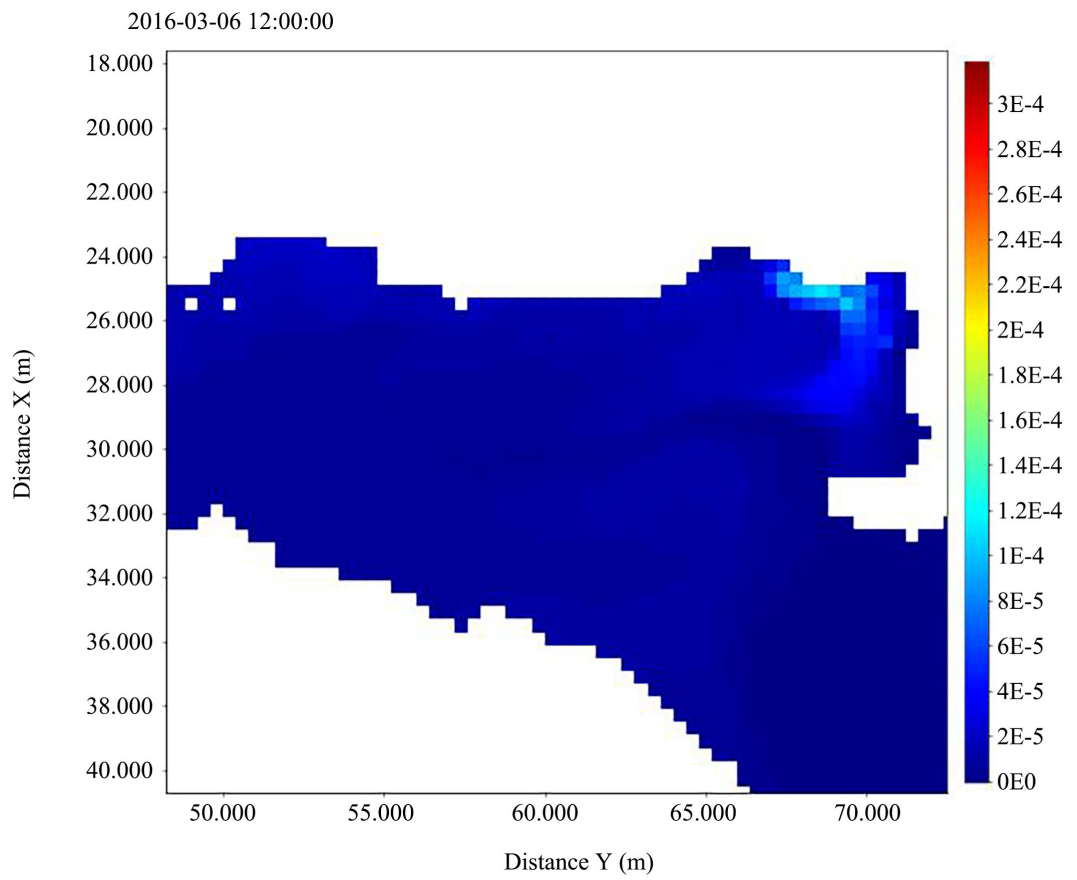

(a)

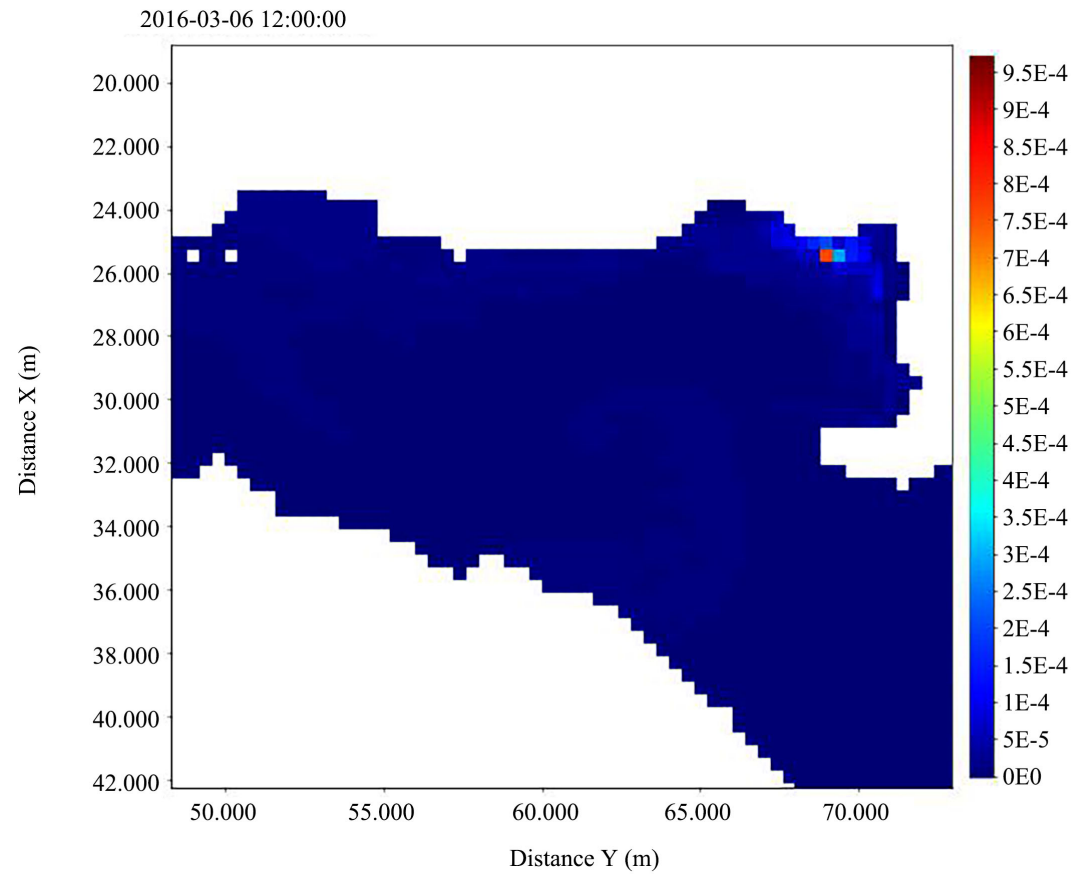

(b)

Figure 9. Color representation of the dimensionless concentration of the tracer 7 conservative tracer, derived from the disposal of liquid municipal waste by Diffuser 5 in the Aliveri region, at a winter time (6-3-2016): (a) at the surface, (b) at the bottom. 


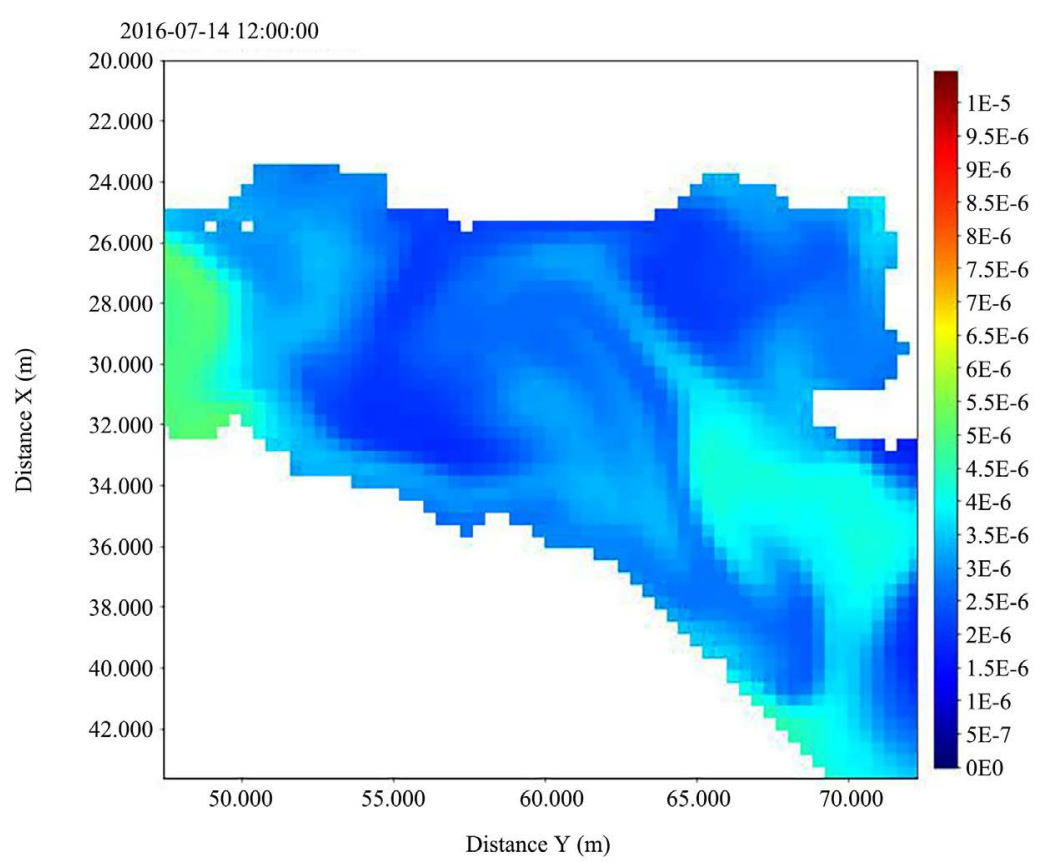

(a)

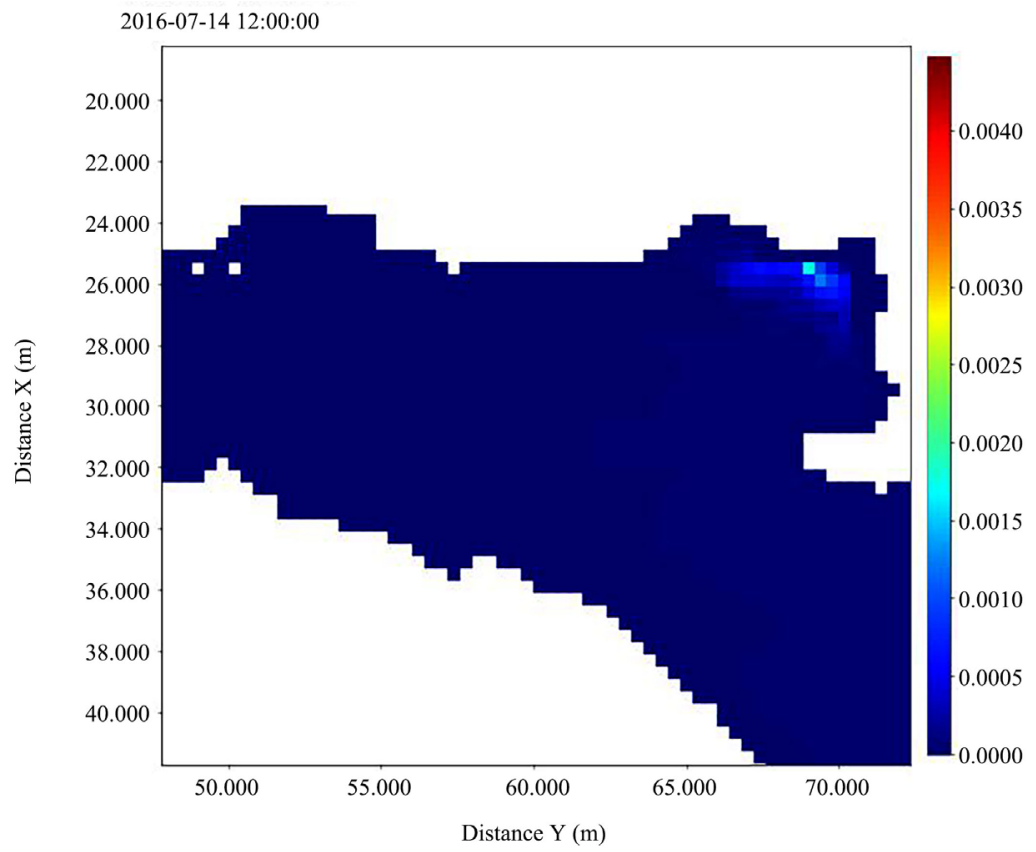

(b)

Figure 10. Color representation of the dimensionless concentration of the conservative tracer 7, derived from the disposal of municipal waste water by Diffuser 5 in the Aliveri region, at a summer time (14-7-2016): (a) at the surface, (b) at the bottom.

Figure 11(a) shows the change in the depth of the dimensional concentration of tracer 7, derived from Diffurer 5 at the Aliveri position. As it turns out, despite the fact that it is winter time (16-03-2016, 12:00), there is a slight stratification of density (Figure 11(b)). The stratification gradient is $4.5 \times 10^{-5} \mathrm{~s}^{-2}$, as calculated from the ratio: 


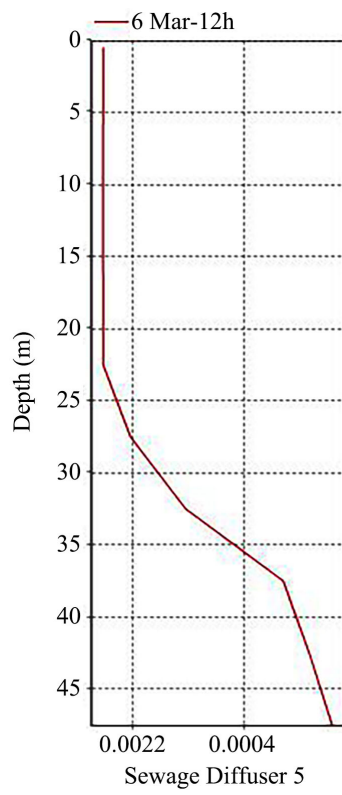

(a)

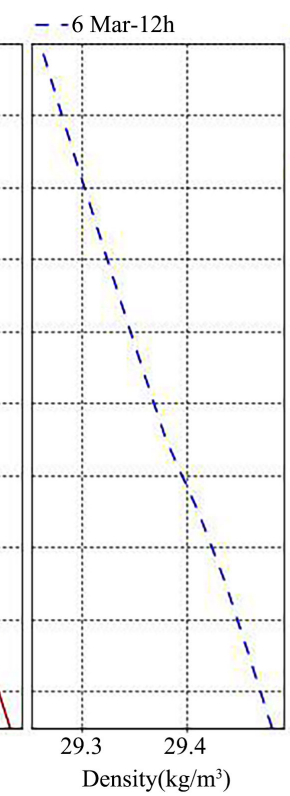

(b)

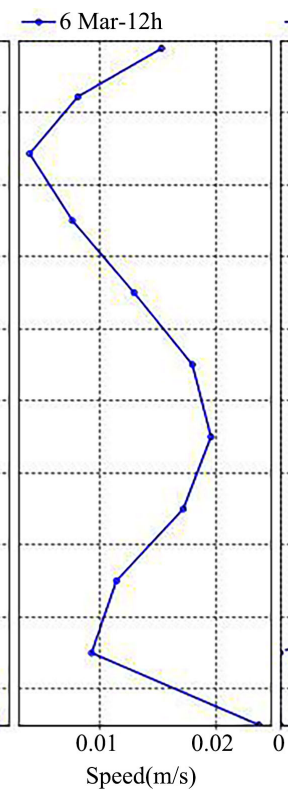

(c)

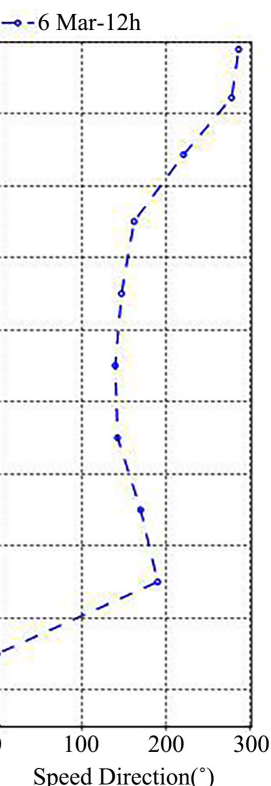

(d)

Figure 11. Change in the water column, in winter time (6-03-2016, 12:00), above Diffurer 5, at Aliveri of: (a) dimensionless concentration of tracer 7, (b) density $\sigma$, (c) the velocity of water, (d) the direction of velocity.

$$
\varepsilon(z)=-\frac{g}{\rho_{b}} \frac{\rho_{s}-\rho_{b}}{H}
$$

where $\varepsilon(z)$ is the stratification gradient, $\rho_{s}$ is the surface density, $\rho_{b}$ is the bottom density, $H$ is the depth of water and $g$ is the acceleration of gravity [30].

However, even this small density stratification substantially traps tracer 7 from the bottom to a depth of about $22 \mathrm{~m}$. Figure 11(c) shows the water velocity values in the water column, which are relatively small, and Figure 11(d) shows the direction of velocity.

Much more pronounced is the density stratification (Figure 12(b)) during the summer time (14-07-2016, 12:00), above the Diffurer 5 in the Aliveri position. The stratification gradient calculated from Equation (1) is $5.4 \times 10^{-4} \mathrm{~s}^{-2}$, that is, about 10 times higher than the corresponding winter season. This high density stratification results in the reduction of vertical mixing and the tracer 7 being trapped below a depth of $32 \mathrm{~m}$ (Figure 12(a)). The concentration is almost zero to the upper layers of water. Figure 12(c) and Figure 12(d) again give the values of water velocity and direction in the water column above Diffuser 5.

\subsection{Concentration of Drainage Traces at Characteristic Selected Control Points}

It is important to consider how some areas of high economic, tourist and environmental value in the Euboean Gulf are affected by the outflow of liquid municipal waste and within this complex hydrodynamic field. For this purpose five surface cells P1, P2, P3, P4, P5 have been designated in the areas of Politika, 


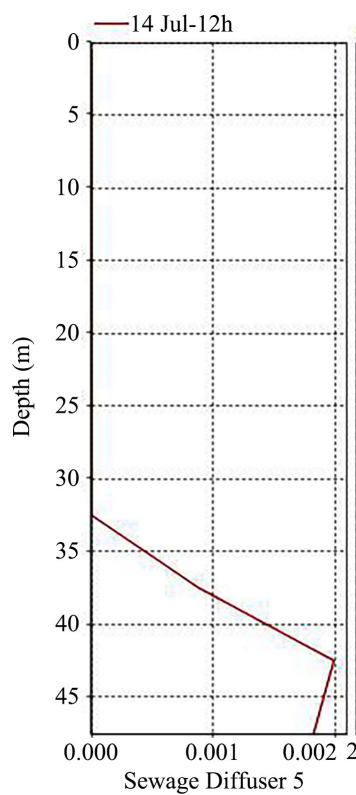

(a)

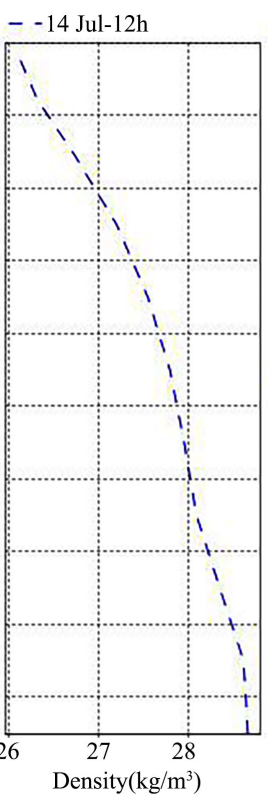

(b)

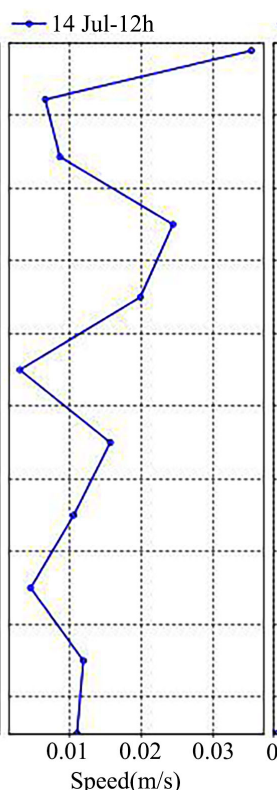

(c)

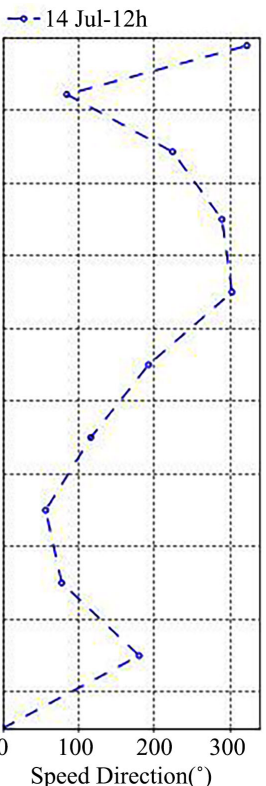

(d)

Figure 12. Change in the water column, in summer time (14-07-2016, 12:00), above Diffurer 5, at Aliveri of: (a) Dimensionless concentration of tracer 7; (b) Density $\boldsymbol{\sigma}$, (c) The velocity of water; (d) The direction of velocity.

Chalkis, Eretria, Amarinthos and Aliveri respectively, as shown in Figure 8. The mean daily change in the concentration of conservative passive indicators is examined here, derived from the disposal of liquid urban waste water from the five diffusers (Diffuser 1 to Diffuser 5) and the concentration of suspended solids for a simulation period of one year. Note that any conservative tracer is contained in the disposed treated urban wastewater with dimensionless initial concentration 1, as well as the suspended solids, with initial concentration, reported in Table 1.

In Figure 13, the mean daily change over time of the concentration of conservative passive indicators, derived from the disposal of processed municipal waste, at the aforementioned checkpoints P1 to P5 is examined. Figure 13(a) shows that at point P1 of the Politika region of the North Euboean, higher concentrations of passive conservative pollutants originating from Diffuser 2, located in the South Euboean and smaller than the local Diffuser 1, are observed. This is due, firstly, to Diffuser 2's significantly higher wastewater supply, and secondly, to the tide, which transports pollutants from Diffuser 2 of South Euboea to point P1 of North Euboea. It should be noted that due to the narrow width of Evripus strait of only $40 \mathrm{~m}$, the velocity field created in this area presents high values, with maximum speeds in the strait of about $2.5 \mathrm{~m} / \mathrm{s}$. In the same Figure 13(a), the concentration of suspended solids derived from both Diffuser1 and Diffuser2 diffusers is presented.

At the control point P2 of the South Euboean Gulf, concentrations of conservative pollutants (Figure 13(b)) appear, coming only from the very close Diffuser 2, through which the treated waste from the city of Chalkida is disposed. Obviously, due to low supply and long distance it does not reach point 
P2 significantly pollution from the Diffuser 1 in north Euboean, nor from Diffuser 3, Diffuser 4, Diffuser 5, which are some distance southeast of the control point $\mathrm{P} 2$.

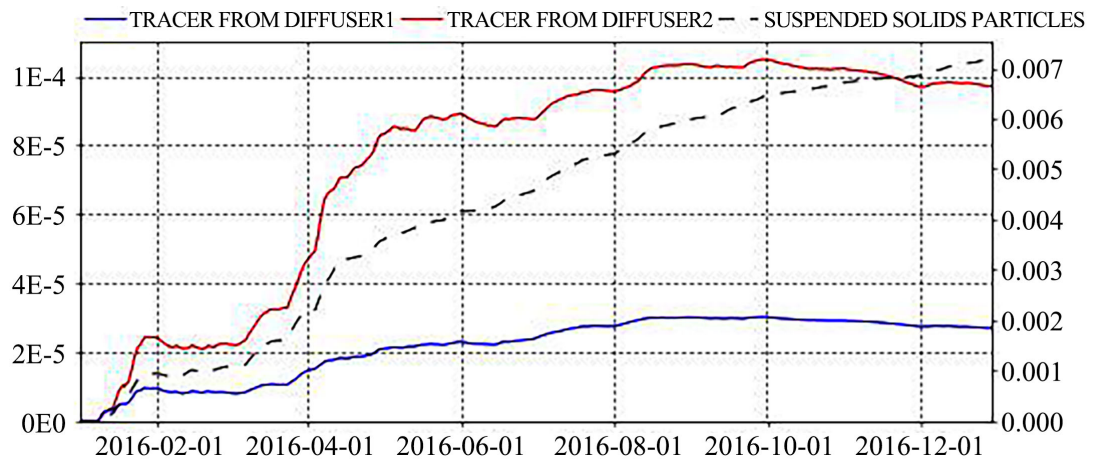

(a)

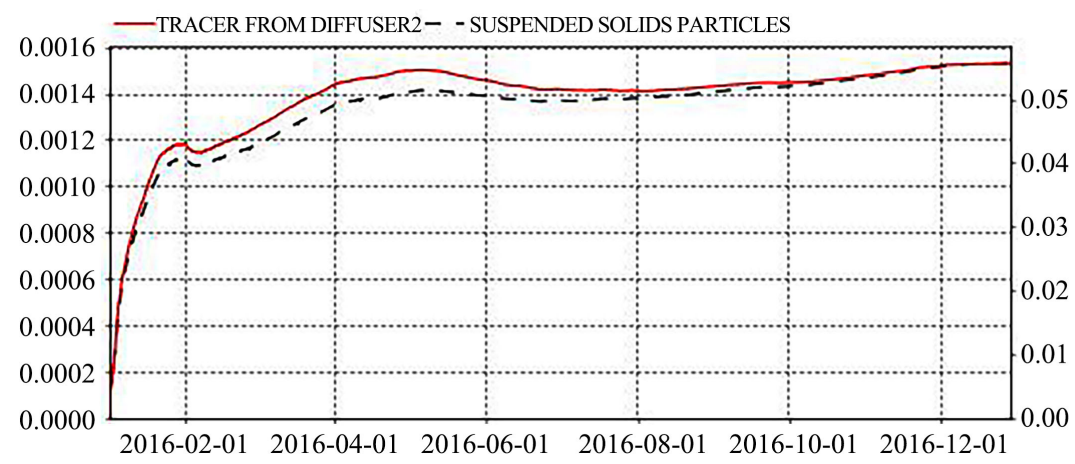

(b)

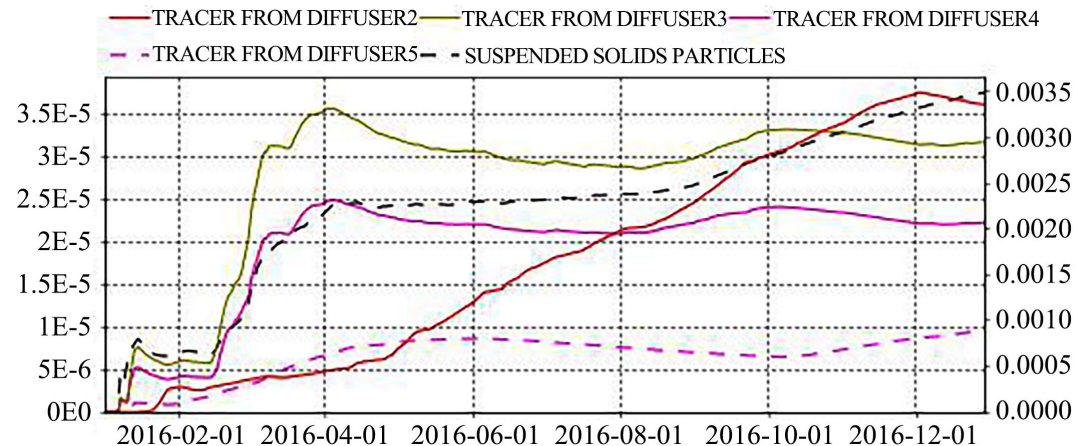

(c)

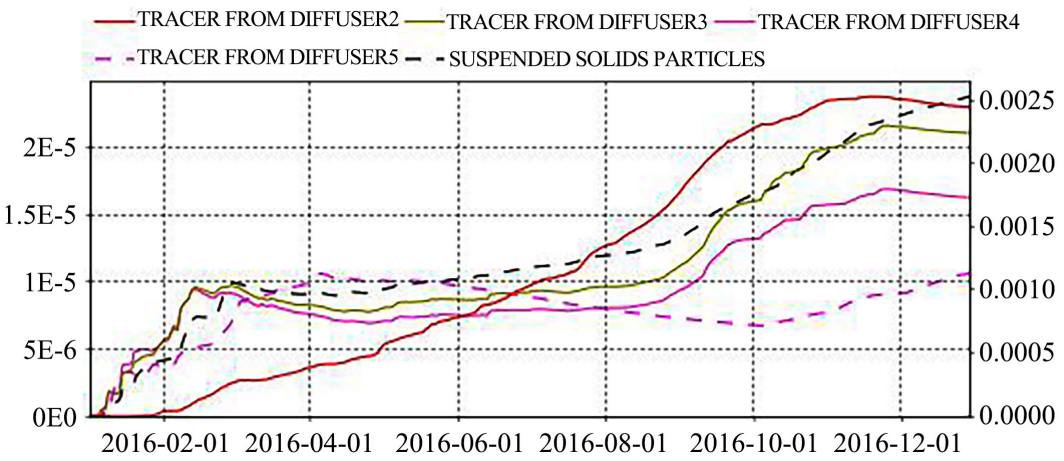

(d) 


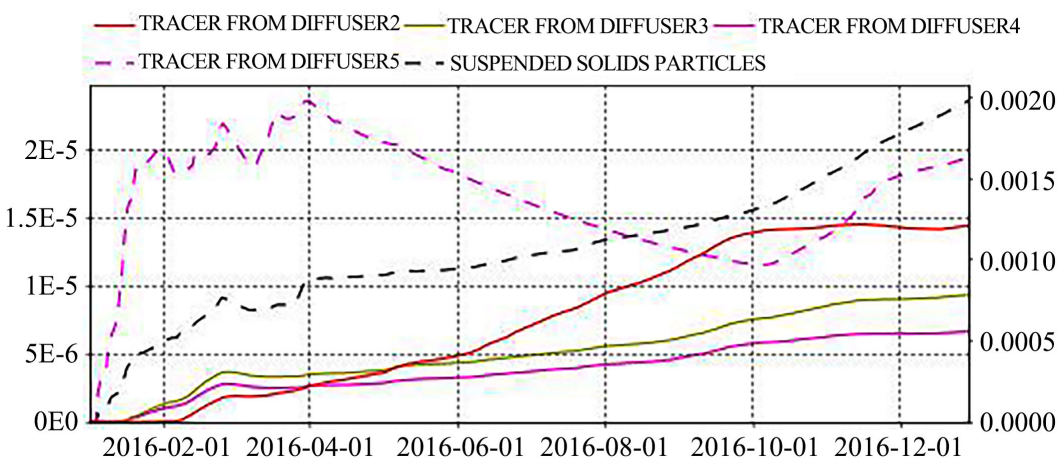

(e)

Figure 13. Average daily variation of conservative passive indicators, derived from the disposal of municipal waste water from five diffusers (Diffuser 1 to Diffuser 5) and suspended solids at the control points: (a) P1, (b) P2, (c) P3, (d) P4 and (e) P5, for a simulation period of one year.

Concerning point P3 in the Eretria region, Figure 13(c) shows that it is polluted by both the nearby Diffuser 3 and Diffuser 4, as well as the more distant Diffuser 2 (with significant pollution values) and Diffuser 5 of the South Euboean Gulf. A similar situation applies to the control point P4 of the Amarinthos area of South Euboean. In Figure 13(d) it is observed that up to the 8th month of the simulation, it is mainly polluted by the nearby sewers (Diffuser 3, Diffuser 4 and Diffuser 5), whereas from August onwards the pollution from Diffuser 2 is dominant. Note that the Diffuser 2 is at a longer distance, but it has a significantly larger supply than the others. Even at the remote control point P5 of the Aliveri area, Diffuser 2 pollution is significant, especially after October (Figure 5(e)).

The suspended solids entering the Euboean Bay are derived from inorganic processes occurring in Waste Water Treatments plants (WWT). They have a diameter of $2.5 \mu \mathrm{m}$, a density of about $2650 \mathrm{Kg} / \mathrm{m}^{3}$ [31] [32], remain in suspension for a long time and can adsorb toxic metals such as nickel (Ni) and zinc ( $\mathrm{Zn})$ on their surface [33], either during their diffusion or in the process of collecting them on WWT. In many cases, the collection and treatment of waste water, other than urban waste, also includes industrial waste water, which is transported through canals or streams to coastal areas. Thus, the lower layers of these coastal areas are burdened by sedimentation and deposition, with the risk of future water quality deteriorating.

For this reason, Figure 14 shows the change in the concentration of suspended solids over time at control points P2, P3, P4 and P5. The same diagrams show the water residence time at these points. At all these four checkpoints (Figures 14(a)-(d)) an increase in the concentration of suspended solids is observed as the mean residence time of the water increases. Admittedly, the residence time is after 12 months of simulation of two months, which means a good renewal of water at these points, but shorter than the rest of the computing space, as shown in Figure 4(a). 


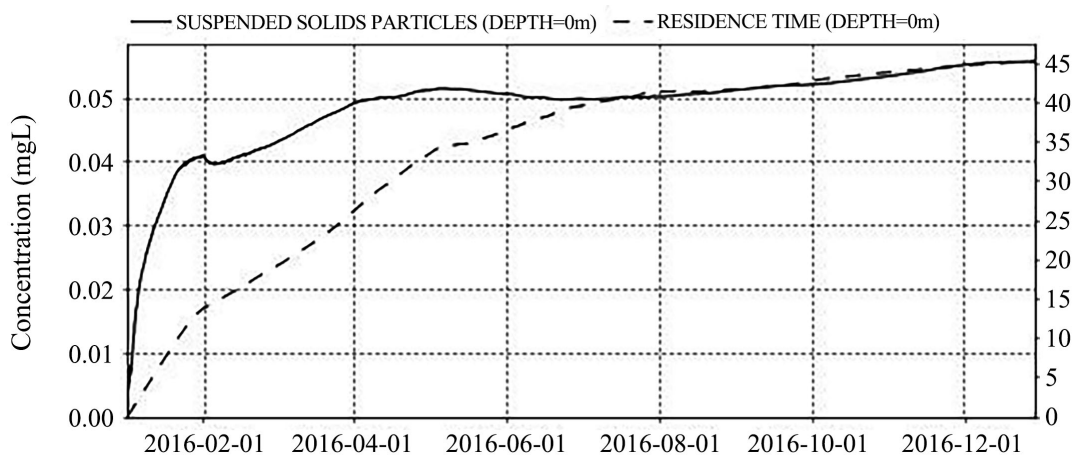

(a)

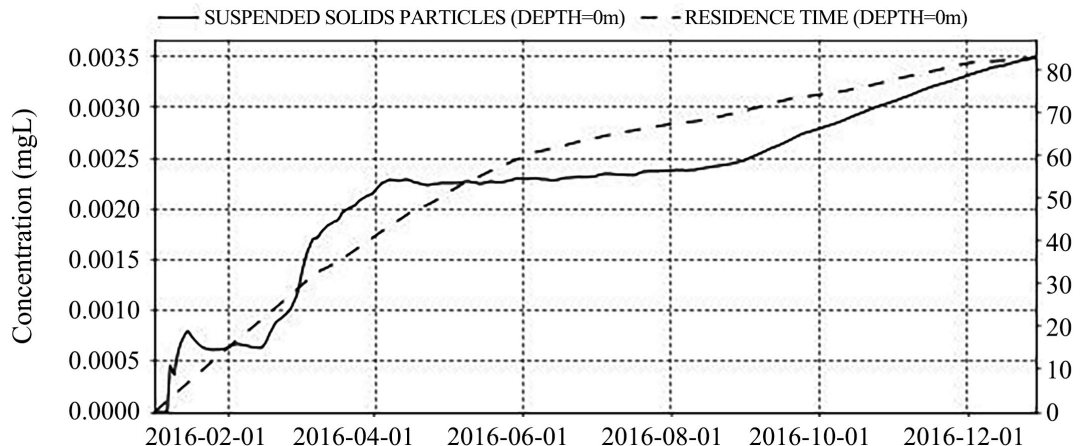

(b)

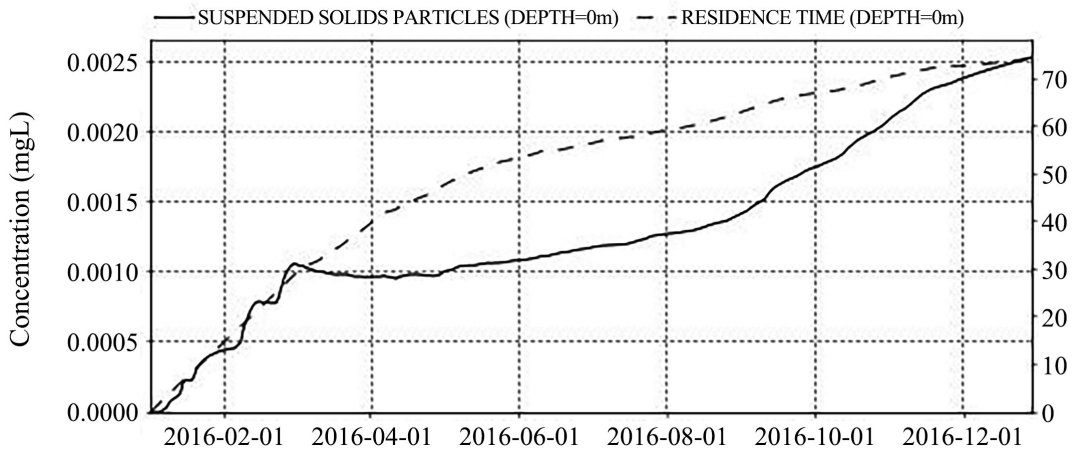

(c)

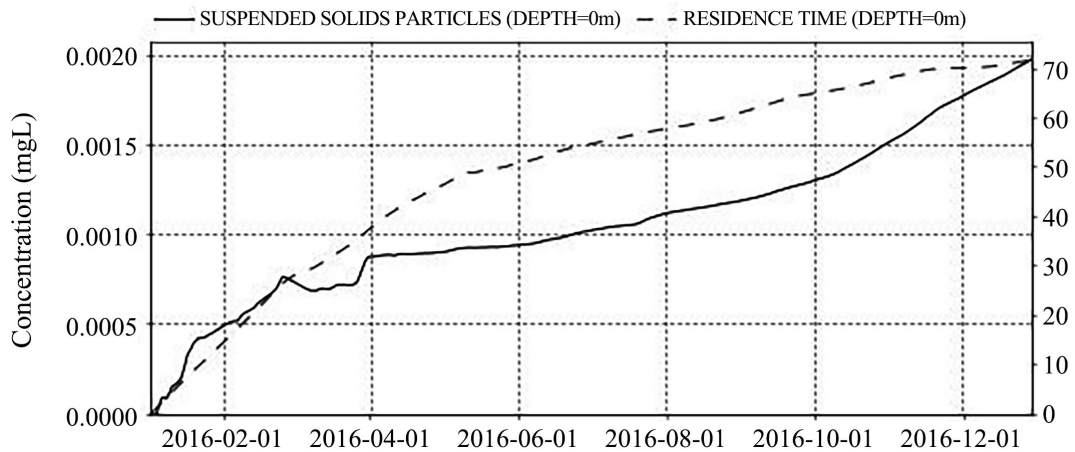

(d)

Figure 14. Average daily change in the concentration of suspended solids emanating from the five diffusers (Diffuser 1 to Diffuser 5), compared to the average daily residence time of water at the surface of the control points: (a) P2, (b) P3, (c) P4 and (d) P5. 


\section{Discussion}

An interesting question that arises is whether tide ultimately contributes to better mixing and dispersing of pollutants and to better renewal of water or vice versa, as it restores remote pollutants that were previously available. Although the question is purely theoretical and without practical application, its answer is scientifically interesting. Since the answer to this query for the whole simulation field is extensive, it will then provide an indicative answer for only one point, the control point P2. This point is selected as it is very close to Diffuser 2, which has the largest supply of treated wastewater, with a small depth of discharge (only 10 $\mathrm{m}$ ) and is also close to Euripus Strait, where tidal flow velocity reaches high values $(2.5 \mathrm{~m} / \mathrm{s})$.

In Figure 15(a) it is plotted over time for control point P2 the dimensional concentration of a conservative tracer derived from neighboring Diffuser 2, with and without tide, as shown by the numerical simulation with the ELCOM model. As can be seen from this figure, the presence of tides results in much lower concentrations all day long.

In Figure 15(b), the concentration of suspended particles, derived from all (and all five) diffusers, with and without tides, is plotted at the same control point P2. Again, the tide is beneficial as it results in significantly lower concentrations, all day long.

From Figure 15(c) is concluded that the average daily velocity of water in tidal conditions is almost twice the average daily velocity in the absence of tide. Also, from Figure 15(c) it is shown that the average residence time of water at the P2 control point is, for most days, shorter than in tidal conditions. In fact, in the last months of the year, the water's residence time is almost half in tidal conditions compared to the one in its absence. Therefore, for control point P2, it appears that the tide has a positive effect on faster water renewal and faster mixing and removal of the resulting conservative pollutants from the disposal of liquid municipal waste.

\section{Conclusions}

The mixing characteristics in the marine environment of the Euboean Gulf were simulated under tide, meteorological and oceanographic conditions. The ELCOM three-dimensional hydrodynamic model has been used to simulate the effect of the tide, as well as atmospheric forcing in the hydrodynamic circulation and in pollutant mixing.

The age of the water in each cell was calculated. Satisfactory renewal of Euboean waters was found in both surface and bottom cells. After about 11 months, water is almost completely renewed for depths greater than $30-35 \mathrm{~m}$ with "pure" water derived from the boundary conditions, while the surface layers are older. It is concluded that the tide and the wind mainly affect the surface layers (up to $30-35 \mathrm{~m}$ ) and less on the deeper ones. It seems that in surface layers the tide and the wind restore the water of the computational space, thus preventing its renewal with "pure" water of the open sea. 


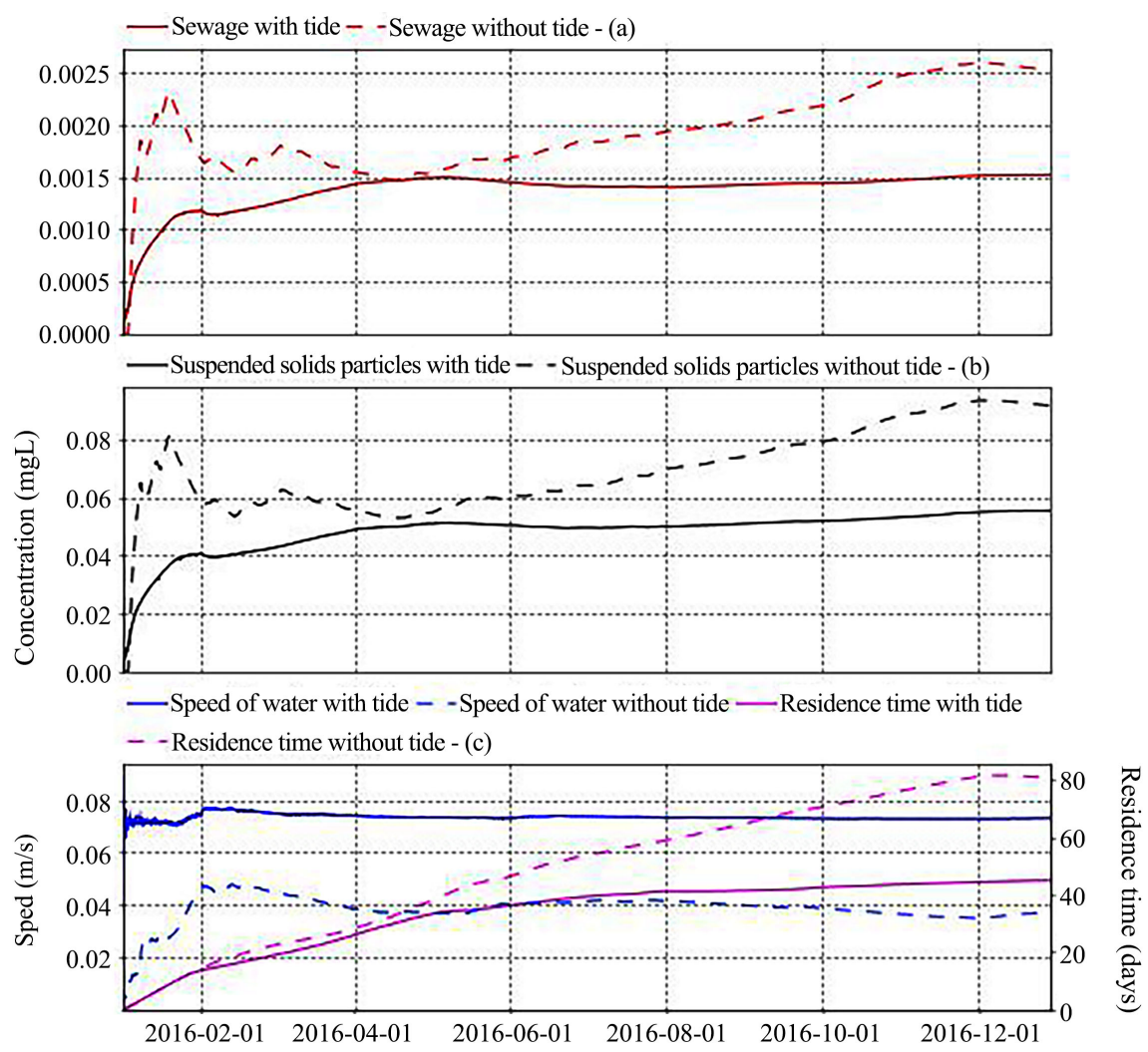

Figure 15. Daily variation over time at control point P2, with and without tide: (a) The concentration of conservative tracer derived from the disposal of treated wastewater by Diffuser 2; (b) The concentration of suspended solids derived from the five diffusers; (c) Average daily velocity and average residence time of water.

The mixing and dilution in the far field of pollutants, contained in the treated municipal waste of five diffusers, installed and operating in the research area, was simulated. It was observed that during the summer season the concentrations of pollutants on the surface are much lower than those of the winter season. It was found that this variation was due to the density stratification, which is much greater during the summer season. It has been found that the presence of even a small density stratification contributes to the entrapment of pollutants in the deeper layers, preventing vertical mixing and leading to low concentrations in the upper layers of water.

The combined impact of municipal waste water effluents from the five diffusers operating in the research area was investigated in five selected areas of high economic, tourist and environmental value (control points P1, P2, P3, P4, P5). It has been shown that the pollution of control point P1 of the North Euboean Gulf is less due to the local Diffuser 1 and more to the Diffuser 2 of the South Euboean Gulf, since the latter, on the one hand, has greater waste water supply and on the other due to the transfer of pollutants through the pond South to the North Euboean, due to the high flow velocities in this area. The significant effect of Diffuser 2 is also evident at the other control points P3, P4, P5, which appear to receive greater amounts of pollutants than their nearest diffusers. But in the 
end, there is a short residence time in the water for these points, and therefore a satisfactory renewal of the water bodies, but shorter than the rest.

Finally, at control point P2, which is very close to Diffuser 2 with the highest effluent treatment and a small (only $10 \mathrm{~m}$ ) depth of discharge, it was investigated whether the presence of tide contributes to better mixing and dispersing of pollutants and to better water or on the contrary, as it restores remote pollutants that were released earlier. It has been found that the presence of tides results in significantly lower concentrations all day long. Also, the water residence time at this point in most days is shorter in tidal conditions than without it. In fact, in the last months of the year, the water's residence time is almost half in tidal conditions compared to the one in its absence. That is to say, for this very important control point, the presence of tides has a positive effect on the faster renewal of water and the faster mixing and removal of the resulting conservative pollutants from the disposal of liquid municipal waste.

\section{Conflicts of Interest}

The authors declare no conflicts of interest regarding the publication of this paper.

\section{References}

[1] Pirooznia, M., Emadi, S.R. and Alamdari, M.N. (2016) The Time Series Spectral Analysis of Satellite Altimetry and Coastal Tide Gauges and Tide Modeling in the Coast of Caspian Sea. Open Journal of Marine Science, 6, 258-269. https://doi.org/10.4236/ojms.2016.62021

[2] Onguene, R., et al. (2015) Overview of Tide Characteristics in Cameroon Coastal Areas Using Recent Observations. Open Journal of Marine Science, 5, 81-98. https://doi.org/10.4236/ojms.2015.51008

[3] Manasrah, R. (2013) Tide Variation and Signals during 2000-2004 in the Northern Gulf of Aqaba, Red Sea. Natural Science, 5, 1264-1271. https://doi.org/10.4236/ns.2013.512154

[4] Pous, S., Carton, X. and Lazure, P. (2012) A Process Study of the Tidal Circulation in the Persian Gulf. Open Journal of Marine Science, 2, 131-140. https://doi.org/10.4236/ojms.2012.24016

[5] Vanlede, J., Coen, L. and Deschamps, M. (2014) Tidal Prediction in the Sea Scheldt (Belgium) Using a Combination of Harmonic Tidal Prediction and 1D Hydraulic Modeling. Natural Resources, 5, 627-633. https://doi.org/10.4236/nr.2014.511055

[6] Jeyar, M., Chaabelasri, E.M. and Salhi, N. (2015) Computational Modeling of Tidal Effect on Wastewater Dispersion in Coastal Bays, Case of Tangier's Bay (Morocco). Journal of Materials and Environmental Science, 6, 1715-1718.

[7] Vaselali, A. (2009) Modeling of Brine Waste Discharges Spreading under Tidal Currents. Journal of Applied Sciences, 9, 3454-3468. https://doi.org/10.3923/jas.2009.3454.3468

[8] Abualtayef, M., Al-Najjar, H., Mogheir, Y. and Seif, A.K. (2016) Numerical Modeling of Brine Disposal from Gaza Central Seawater Desalination Plant. Arabian Journal of Geosciences, 9, 572. https://doi.org/10.1007/s12517-016-2591-7

[9] Livieratos, E. (1980) The $\mathrm{M}_{2}$ Sea-Tidal Propagation in the Evoikos Bay. Technika 
Chronika, 5, 48-55.

[10] Eginitis, D. (1929) The Problem of the Tides of Euripus. Astronomische Nachrichten, 236, 321. https://doi.org/10.1002/asna.19292361904

[11] Endros, A. (1915) Die Gezeiten, Seiches und Stromungen des Meeresbei Aristoteles. Sitzungsberichte der Bayerischen Akademie der Wissenschafter (math.-phys.), Kl, 99.

[12] Sterneck, R.V. (1916) ZurTheorie der Euripus-Stromungen. Sitzungsberichte der Akademie der Wissenschafter in Wien (Abt. IIa).

[13] Defant, A. (1961) Physical Oceanography Volume II. Pergamon Press, London.

[14] Tsimplis, M.N. (1997) Tides and Sea-Level Variability at the Strait of Euripus. Estuarine, Coastal and Shelf Science, 44, 91-101. https://doi.org/10.1006/ecss.1996.0128

[15] Wöppelmann, G. and Marcos, M. (2012) Coastal Sea Level Rise in Southern Europe and the Non-Climate Contribution of Vertical Land Motion. Journal of Geophysical Research, 117, C01007. https://doi.org/10.1029/2011JC007469

[16] Ferrarin, C., Bellafiore, D.,Sannino, G., Bajo, M. and Umgiesser, G. (2018) Tidal Dynamics in the Inter-Connected Mediterranean, Marmara, Black and Azov Seas. Progress in Oceanography, 161, 102-115. https://doi.org/10.1016/j.pocean.2018.02.006

[17] Tsimplis, M.N. and Shaw, G.P. (2010) Seasonal Sea Level Extremes in the Mediterranean Sea and at the Atlantic European Coasts. Natural Hazards and Earth System Sciences, 10, 1457-1475. https://doi.org/10.5194/nhess-10-1457-2010

[18] Marcos, M., Tsimplis, M.N. and Shaw, A.G.P. (2009) Sea Level Extremes in Southern Europe. Journal of Geophysical Research, 114, C01007.

https://doi.org/10.1029/2008JC004912

[19] Poulos, S., Drakopoulos, P., Leontaris, S., Tsapakis, E. and Hatjiyianni, E. (2001) The Contribution of Tidal Currents in the Sedimentation of Strait of Avlida, Southern Evoikos Gulf, Greece. Proceedings of the 9th International Congress, Athens, 26-28 September 2001, 731-736.

[20] Kontoyiannis, H., Panagiotopoulos, M. and Soukissian, T. (2015) The Euripus Tidal Stream at Halkida/Greece: A Practical, Inexpensive Approach in Assessing the Hydrokinetic Renewable Energy from Field Measurements in a Tidal Channel. Journal of Ocean Engineering and Marine Energy, 1, 325-335. https://doi.org/10.1007/s40722-015-0020-8

[21] Tsirogiannis, E., Angelidis, P. and Kotsovinos, N. (2019) Hydrodynamic Circulation under Tide Conditions at the Gulf of Evoikos, Greece. Computational Water, Energy, and Environmental Engineering, 8, 57-78.

https://doi.org/10.4236/cweee.2019.83004

[22] Kopasakis, K.I., Georgoulas, A.N., Angelidis, P.B. and Kotsovinos, N.E. (2012) Simulation of the Long-Term Fate of Water and Pollutants, Transported from the Dardanelles Plume into the North Aegean Sea. Applied Ocean Research, 37, 145-161.

[23] Kopasakis, K., Georgoulas, A., Angelidis, P. and Kotsovinos, N. (2012) Numerical Modeling of the Long-Term Transport, Dispersion and Accumulation of Black Sea Pollutants into the North Aegean Coastal Waters. Estuaries and Coasts, 35, 15301550. https://doi.org/10.1007/s12237-012-9540-9

[24] Spillman, C.M., Imberger, J., Hamilton, D.P., Hipsey, M.R. and Romero, J.R. (2007) Modelling the Effects of Po River Discharge, Internal Nutrient Cycling and Hydrodynamics on Biogeochemistry of the Northern Adriatic Sea. Journal of Marine Systems, 68, 167-200. https://doi.org/10.1016/j.jmarsys.2006.11.006 
[25] Alosairi, Y., Imberger, J. and Falconer, R.A. (2011) Mixing and Flushing in the Persian Gulf (Arabian Gulf). Journal of Geophysical Research: Oceans, 116, C03029.

[26] Kotsovinos, N. (1987) The Problem of Pollution in the Gulf of Evoikos. In: Proceedings of the International Scientific Conference "The City of Chalkida", Company of Euboean Studies, Chalkida, 353-387.

[27] Skaloumpakas, K. (2011) Study of the Tidal Energy Potential at the Euripus Strait and Operating Modes through Tidal Turbine Installation. Degree Thesis, National Technical University of Athens, Athens.

[28] Hodges, B. and Dallimore, C. (2010) ELCOM Science Manual. CWR, University of Western Australia, Crawley.

[29] Hodges, B. and Dallimore, C. (2010) ELCOM User Manual. CWR, University of Western Australia, Crawley.

[30] Fischer, H.B., List, E.J., Koh, R., Imberger, J. and Brooks, N.H. (1979) Mixing in Inland and Coastal Waters. Academic Press, New York.

[31] Post, J.L. (1989) Moisture Content and Density of Smectites. Geotechnical Testing Journal, 12, 5-10. https://doi.org/10.1520/GTJ10971J

[32] Douglas, L.A. (1990) Soil Micromorphology: A Basic and Applied Science. In: Proceedings of the 8 th International Working Meeting of Soil Micromorphology, Elsevier, San Antonio, 466.

[33] Premovic, P.I., Todorovic, B.Z. and Pavlovic, M.S. (2007) Cretaceous-Paleogene Boundary Fish Clay at Hojerup (StevnsKlint, Denmark): Trace Metals in Kerogen. Bulletin de la Société Géologique de France, 178, 411-421.

https://doi.org/10.2113/gssgfbull.178.5.411 